\title{
Experimental Analysis of Eccentric Compression Performance of Larch Wood-Steel Composite Columns
}

\author{
Junren Wang, ${ }^{1,2}$ Shaowei Duan $\mathbb{C D}^{1,2}$ Jiewei He $\mathbb{D}^{1,2}$ and Zhifeng Wang ${ }^{1,2}$ \\ ${ }^{1}$ College of Civil Engineering, Central South University of Forestry and Technology, Changsha, Hunan 410004, China \\ ${ }^{2}$ Hunan Province Key Laboratory of Engineering Rheology, Central South University of Forestry and Technology, Changsha, \\ Hunan 410004, China \\ Correspondence should be addressed to Shaowei Duan; 450741204@qq.com
}

Received 28 March 2019; Revised 29 May 2019; Accepted 15 July 2019; Published 6 August 2019

Academic Editor: Jorge Branco

Copyright (c) 2019 Junren Wang et al. This is an open access article distributed under the Creative Commons Attribution License, which permits unrestricted use, distribution, and reproduction in any medium, provided the original work is properly cited.

In this paper, a new steel-wood composite column with an $\mathrm{H}$-shaped section was proposed. In order to form an $\mathrm{H}$-shaped cross section, a larch board is fixed on the outer surface of the left and right edges of a hot-rolled H-beam by using physical connection. When the eccentricity is the same, eccentric compression tests were carried out on two types of columns by changing the thickness of the larch board, cross-sectional area of the hot-rolled H-beam, and slenderness ratio in composite columns. Therefore, type A is joined by structural glue only with the larch board and hot-rolled H-beam, and type B is joined by both structural glue and bolts. With the variation of strain and deflection, failure process and failure modes of the hot-rolled $\mathrm{H}$-beam and larch from composite columns under various loads were observed, and the ultimate bearing capacity and stability of composite columns were studied. The test results showed that the overall working performance of the hot-rolled H-beam and larch board was good, and the stability of the hot-rolled H-beam column could be effectively improved. With the increase of wood thickness, cross-sectional area of the hot-rolled H-beam, slenderness ratio of composite columns, and the bearing capacity of the specimens were increased. Moreover, a simplified formula was proposed by the superposition principle. The theoretical analysis accorded with the experimental results, thus providing a reference basis for further study and application of similar steel-wood composite columns.

\section{Introduction}

Nowadays, commercial steel structure has been becoming an extensive concern due to several advantages of stable performance, light weight, high strength, good plasticity/ toughness, high degree of assembly, short construction period, less construction waste, and less environmental pollution. However, the wide application of steel can be impeded by its poor stability [1,2]. Wood is a natural, abundant, renewable, and nonpolluting material with long life/durability and good thermal insulation effect. In wood structures, different kinds of wood have different design strength $[3,4]$. In the present study, combined with China's existing poverty alleviation projects, the selection of larch trees and steel structural members is envisaged as the main raw materials, using physical connections to connect hotrolled H-beams with the larch board to form a new type of fabricated component in this paper. For this steel-wood composite column member, the hot-rolled $\mathrm{H}$-beam is used as the main force-bearing member and larch wood provides lateral rigidity for the hot-rolled H-beam to prevent premature buckling and instability of the hot-rolled H-beam. In this way, the steel-wood combination column will have a significant improvement in its bearing capacity and stability due to the combination of the advantages from these two materials.

For the concrete-filled steel tubular (CFST) structure, it is well known that the mechanical properties are of great importance. Some investigations have been performed to reveal the mechanical properties of the CFST structure with different shapes (rectangular, square, or circular) by using various test (axial compression test, biased compression test, and torsion test) [5-14]. The results showed that the overall performance of the CFST structure was excellent, and the 
steel tube composite members can be applied to engineering practice. Moreover, the results of studies on steel-wood composite beams [15-17] showed that the composite members exhibited excellent mechanical properties and good combination effects despite large differences in elastic modulus between steel and wood.

As one of the main bearing components of building structures, CFST structures are often subjected to eccentric compression. Therefore, it is significant to study the deformation characteristics, failure mechanism, and ultimate bearing capacity of steel-wood composite columns under eccentric compression. In the present work, a new type of the $\mathrm{H}$-shaped cross section assembly is formed. The hot-rolled $\mathrm{H}$-beam is used as the force skeleton, and the larch board is fixed on the outer surface of the left and the right flanges of the hot-rolled H-beam by physical connection. As shown in Figure 1, the cross section of the column can be classified into two types: type A (composite column connected only with high-strength structural adhesive) and type B (composite column connected with both bolts and high-strength structural adhesive). In order to study the combined effect of hot-rolled $\mathrm{H}$-shaped steel and larch wood, bias compression tests were carried out on the abovementioned composite columns. Based on the experimental results, a simplified formula is proposed by calculating the bearing capacity of hot-rolled H-beam-larch composite columns. The formula can provide a reference basis for further research and future application of steel-wood composite columns.

\section{Specimen Fabrication and Mechanical Properties of Materials}

2.1. Design and Fabrication of Specimens. In this work, 8 hot-rolled $\mathrm{H}$-shaped steel-larch composite columns were used. Eccentric compression tests were carried out, so each specimen needs to be equipped with brackets, and the eccentricity of each specimen was $30 \mathrm{~mm}$. The specific size parameters of the specimen are shown in Table 1.

The manufacturing processes of the specimen are as follows, as shown in Figure 2:

(1) Larch and hot-rolled H-beam were cut into the required size according to Table 1.

(2) For A-type composite columns, one side of the larch was ground to make it rough, and then, the outer surface of the flange of the hot-rolled H-beam was polished. The removed debris and the surface coating were also beneficial for the surface roughness. For B-type composite columns, percussion drilling should be used in specified places according to the design requirements of bolt layout drawing in Figure 3.

(3) For the A-type column, the high-strength structural adhesive was painted evenly on the outer surface of the flange of the hot-rolled $\mathrm{H}$-section steel, and then the larch board was bond with the hot-rolled $\mathrm{H}$-section steel; for the B-type column, it is necessary to use bolts to consolidate the larch board with the hot-rolled $\mathrm{H}$-section steel where the holes were reserved.

(4) Preliminarily formed specimens were compressed for 72 hours to assure that the high-strength structural adhesive fully contacted with the larch board and hot-rolled H-beam.

(5) In order to ensure the moisture content in the larch board was consistent with the environment, the high-strength structural adhesive was dry and its bonding strength fully developed; the specimens were kept indoors for about 10 days.

(6) According to the brackets arrangement in Table 1, brackets for eccentric compression were installed at both ends of the processed specimens.

(7) Finally, sandpaper and hand grinder were used to remove the glue overflow on the surface.

2.2. Main Performance Indicators of Material Mechanics. The mechanical properties of the larch and hot-rolled H-beam were tested on the Electrohydraulic Servo Universal Testing Machine of Civil Engineering Laboratory of Central South Forestry University, as shown in Figure 4.

The test method accords with the requirements of GB/ T 228.1-2010 (the tensile test of metallic materials at room temperature) and GB/T50329-2012 (standard for test methods of the timber structure). The main mechanical indexes of materials are shown in Table 2.

\section{Eccentric Compression Test of Composite Columns}

3.1. Test Preparation. The eccentric compression test was different from the axial compression test, and the specific design drawings and finished drawings are shown in Figure 5. According to the "Standard for Testing Methods of Wood Structures" (GB/T50329-2012), the unidirectional cutter-reamer support was applied to the composite columns for the eccentric compression test.

As shown in Figure 6, the electrohydraulic servo pressure testing machine, static strain tester, and displacement sensor were used in the present study. The resistance strain gauges with the gauge distance of $80 \mathrm{~mm}$ and $10 \mathrm{~mm}$ were used to measure the strain of wood and steel, respectively. The relevant parameters of the resistor strain gauges are shown in Table 3.

3.2. Test Scheme. The test scheme is shown in Figure 7. The loading speed was controlled at a crosshead speed of $1 \mathrm{~mm} / \mathrm{min}$. The current pressure/displacement values of the lower support were collected automatically. The static strain tester collected the strain and deflection values at $1 /$ 2 of the composite column and the perturbation values at $1 / 4$ and $3 / 4$ heights at the acquisition speed of 5 seconds. At the same time, the current pressure/displacement values of the lower support were collected. The strain and deflection values will be automatically collected by the static strain tester at $1 / 2$ of the composite column and the 


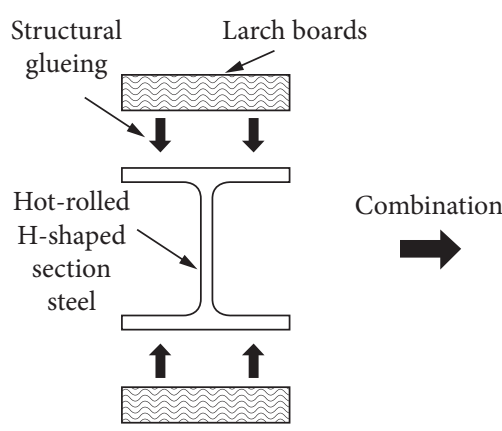

(a)

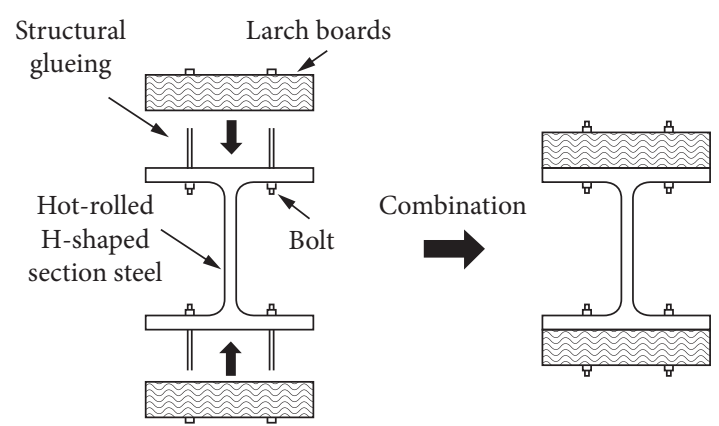

(b)

FIgURE 1: Section form of the composite column: (a) type A composite column section; (b) type B composite column section.

TABLE 1: Main parameters of specimens.

\begin{tabular}{|c|c|c|c|c|c|c|c|c|c|}
\hline & Specimen & $t_{\mathrm{f}}(\mathrm{mm})$ & $t_{\mathrm{w}}(\mathrm{mm})$ & $h_{\mathrm{w}}(\mathrm{mm})$ & $T(\mathrm{~mm})$ & $b(\mathrm{~mm})$ & $h(\mathrm{~mm})$ & $H(\mathrm{~mm})$ & Bracket arrangement \\
\hline \multirow{4}{*}{ A } & Z-1 & 8 & 6 & 100 & 20 & 100 & 146 & \multirow{4}{*}{1000} & \multirow{2}{*}{ 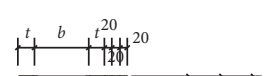 } \\
\hline & $\mathrm{Z}-2$ & 8 & 6 & 100 & 40 & 100 & 186 & & \\
\hline & Z-3 & 10 & 7 & 150 & 20 & 150 & 196 & & \multirow{6}{*}{ m $\quad$ In } \\
\hline & Z-4 & 10 & 7 & 150 & 40 & 150 & 236 & & \\
\hline \multirow{4}{*}{ B } & Z-5 & 8 & 6 & 100 & 20 & 100 & 146 & \multirow{4}{*}{1000} & \\
\hline & Z-6 & 8 & 6 & 100 & 40 & 100 & 186 & & \\
\hline & $\mathrm{Z}-7$ & 10 & 7 & 150 & 20 & 150 & 196 & & \\
\hline & Z-8 & 10 & 7 & 150 & 40 & 150 & 236 & & \\
\hline
\end{tabular}

Note. $t_{\mathrm{f}}, t_{\mathrm{w}}$, and $h_{\mathrm{w}}$ are the thickness, web thickness, and height of the hot-rolled H-beam wing; $t$ is the thickness of the larch board, $b$ is the column width (the larch board has the same width as the hot-rolled H-beam), and $h$ is the total height of the composite column (the sum of the height of the hot-rolled H-beam and the thickness of the wood); and the model of the hot-rolled H-beam is Q235.

perturbation values at $1 / 4$ and $3 / 4$ heights at the acquisition speed of 5 seconds.

Attention was focused on the load-deflection curves, load-strain curves, and lateral deflection curves of $\mathrm{H}$-section steel-larch composite column at $1 / 2$ of the load.

Arrangement of displacement meter: in order to measure the lateral deflection of components under eccentric compression, each composite column was equipped with displacement sensors at $1 / 4,1 / 2$, and $3 / 4$ of the corresponding side height. The specific arrangement is shown in Figure 8.

Layout of strain gauge measuring points: as shown in Figure 9, strain gauges were installed on the larch board and the other 6 on the hot-rolled H-beam.

3.3. Test Phenomenon. For A-type composite columns, when the eccentricity was $30 \mathrm{~mm}$ under eccentric compression, the experimental phenomena are as follows: at the initial stage of loading, the deformation of the hot-rolled $\mathrm{H}$-section steel was almost the same as that of larch wood, both of which could be compressed synergistically due to the action of high-strength structural glue. At this time, the compressive strain increased steadily with the uniform increase of the load, while the tension strain and the deflection hardly changed. The specimen was also kept in a vertical state. The appearance of the test piece was not observed, and no sound could be heard. When the increase of load gradually slowed down, the composite columns began to bend slightly and a slight crackling sound was occasionally heard. When the load increases slowly, the bracket on the pressure side of the combined column was slightly wrinkled and the tension/compression strain increased at a certain speed. While an obvious local degumming was observed at the interface between the section steel and larch wood board, the specimens could still sustain the load. When the load continued to increase, the sound of degumming became more continuous. Furthermore, with the bending phenomenon becoming more and more obvious, the degumming surface expanded rapidly. Finally, the larch board was completely separated from the hot-rolled $\mathrm{H}$-beam and the specimen lost its load-carrying capacity. The failure phenomena are shown in Figures 10(a)-10(h).

For B-type composite columns, under eccentric compression with $30 \mathrm{~mm}$ eccentricity, the experimental phenomena are as follows: at the initial stage of loading, the composite column specimen was at the elastic stage and its strain/deflection was gradually increased with the uniform increase of load. At this time, for the composite column specimen, no obvious bending deformation and sound could be obtained. As the loading continued, the composite column changed into the elastic-plastic stage, at which the composite column appeared on a platform stage. At the platform stage, the load did not increase, while the strain and deflection of the composite column were still increasing. Folds began to appear at the brackets on the compression side, accompanied with the cracking of rubber. However, 


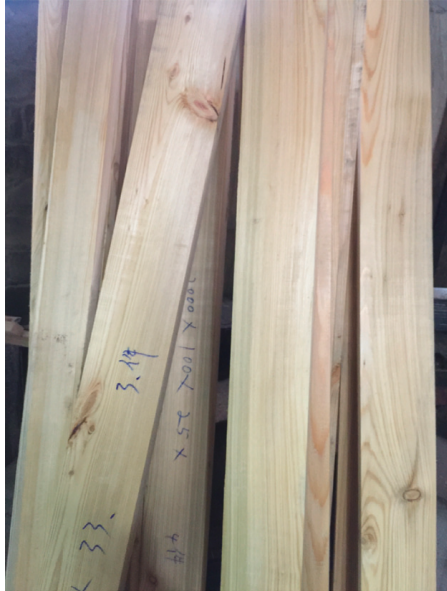

(a)

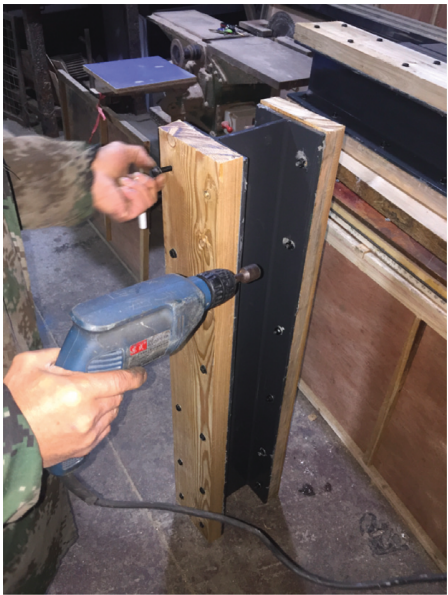

(d)

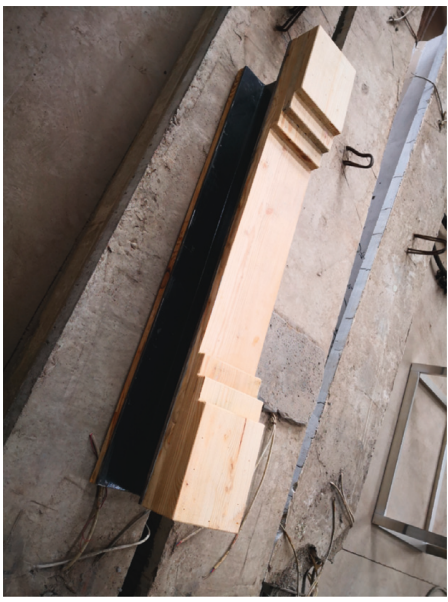

(g)

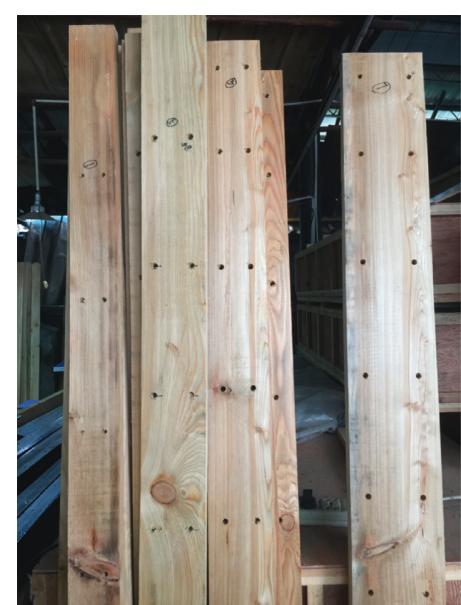

(b)

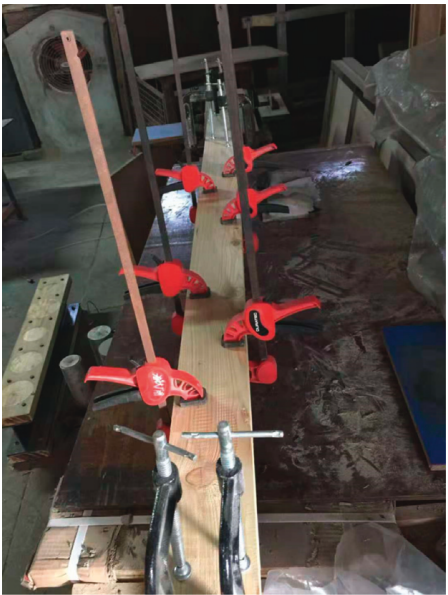

(e)

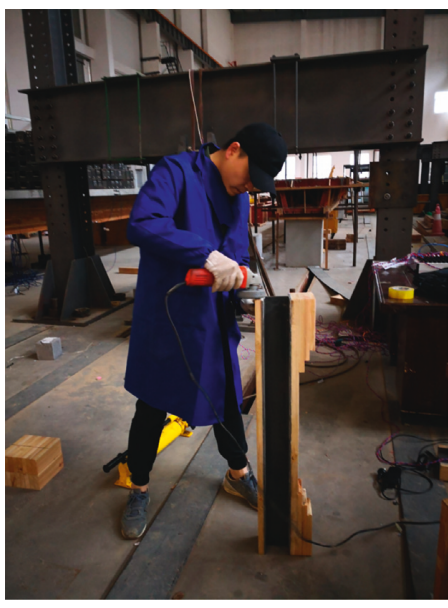

(h)

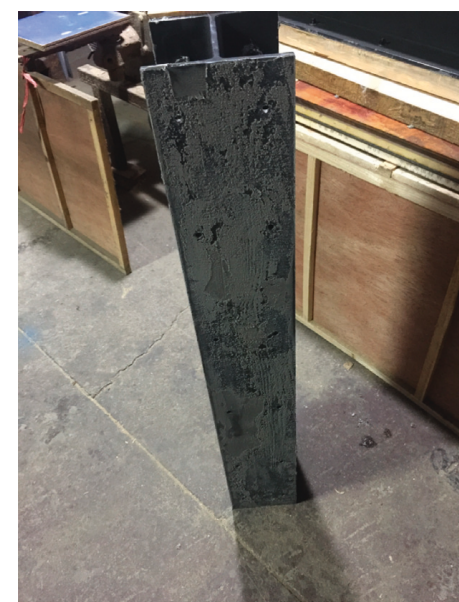

(c)

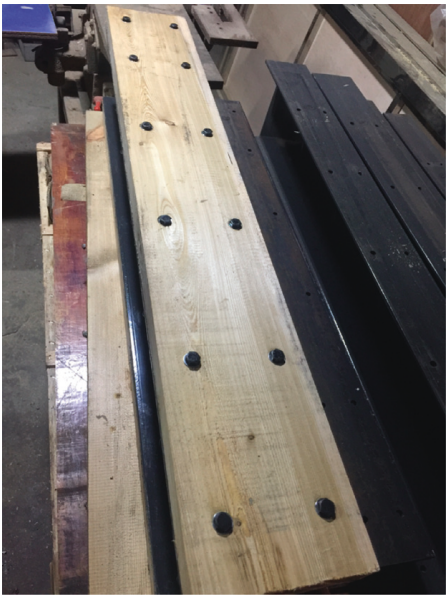

(f)

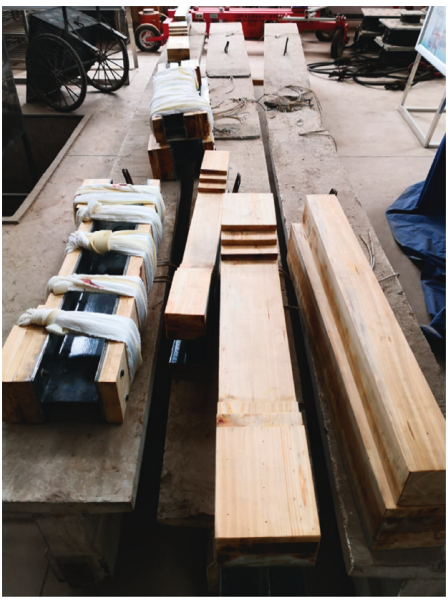

(i)

Figure 2: Manufacturing process of the hot-rolled H-shaped steel-larch composite column: (a) wood cutting; (b) wood board punch; (c) grinding and coating of $\mathrm{H}$-section steel; (d) screw in the bolt; (e) pressurized maintenance; (f) maintenance completed; (g) bracket installed; (h) grinding and leveling the column end; (i) processing completed.

due to the use of bolts, the larch board in the composite column continued to work in coordination with the hotrolled H-beam. At this point, the one-way tool hinge support had a certain degree of rotation and the specimen also began to bend. In the later stage of loading, the phenomenon of bond interface debonding between the upper and lower ends of the compressive side of composite columns became more and more obvious and the load required to compress the 


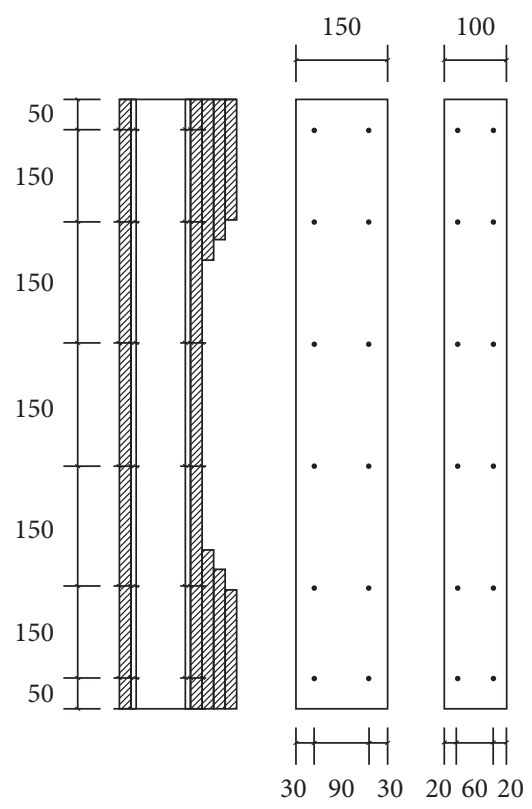

FIgURE 3: Bolt layout.
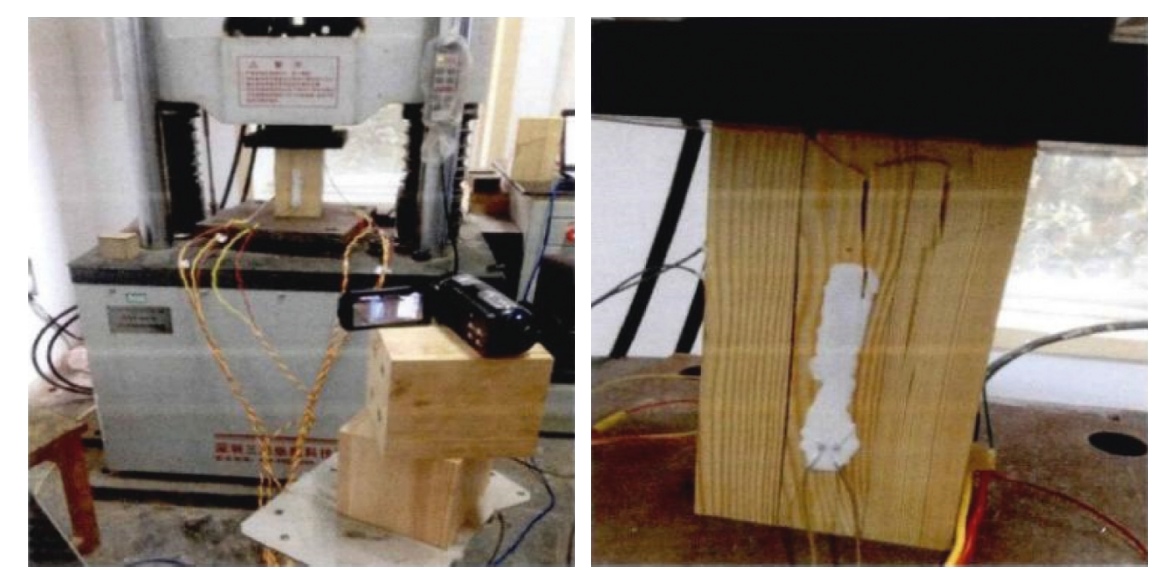

(a)
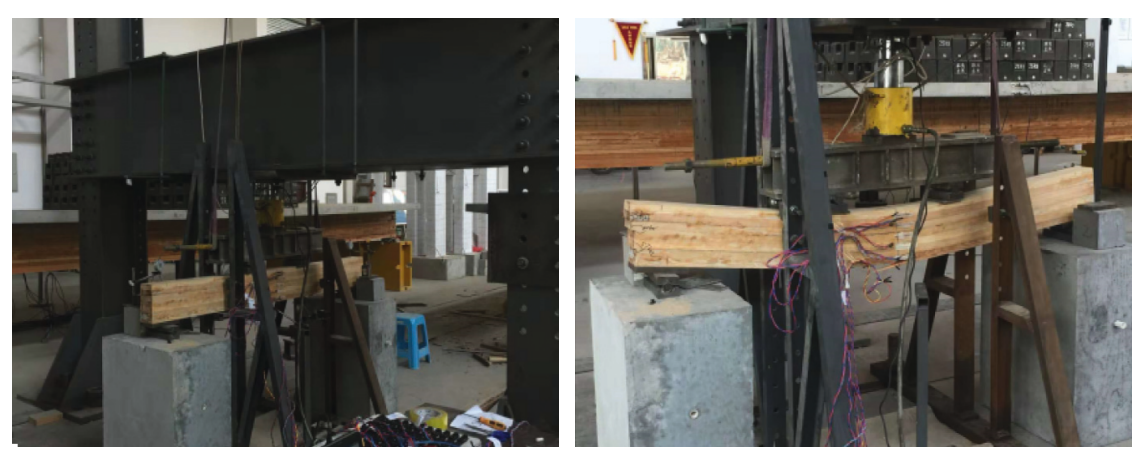

(b)

FIGURE 4: Continued. 

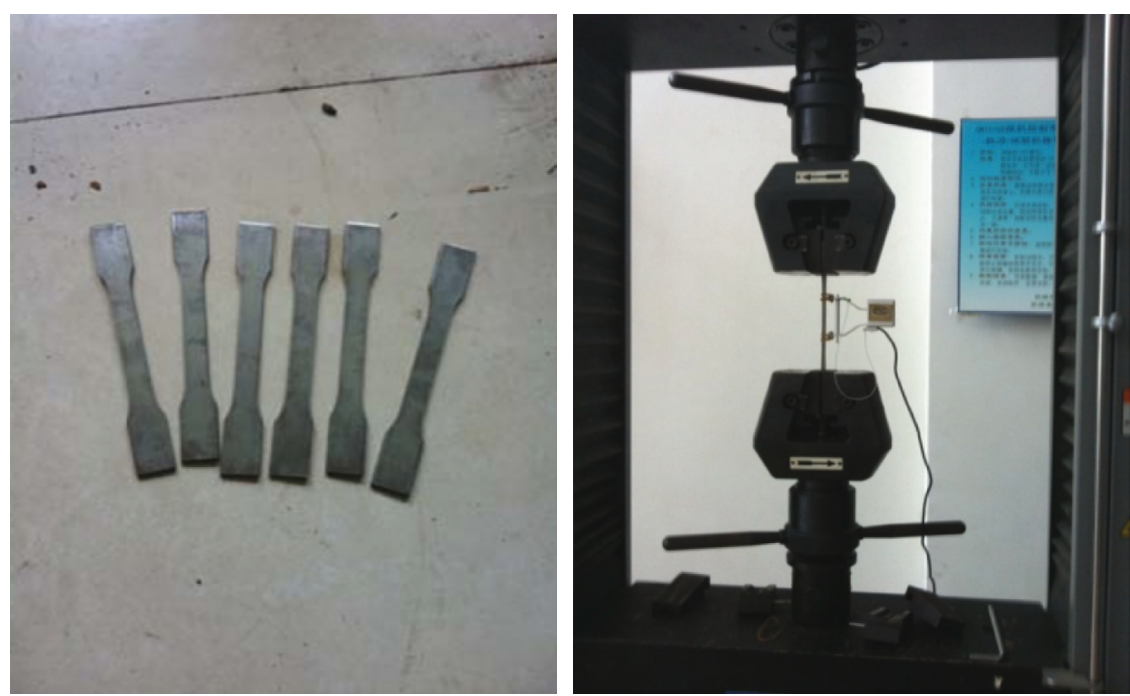

(c)

FiguRE 4: Mechanical properties test of materials: (a) compression test of larch along the grain; (b) bending test of larch wood; (c) mechanical test of steel.

TABLE 2: Mechanical index of materials.

\begin{tabular}{|c|c|c|c|c|c|c|}
\hline Material & $E_{\mathrm{s}}$ & $\sigma_{\text {sy }}$ & $\sigma_{\mathrm{su}}$ & $E$ & $f_{\mathrm{m}}$ & $f_{\mathrm{c}}$ \\
\hline Larch & - & - & - & $14.28 \mathrm{GPa}$ & $70.46 \mathrm{MPa}$ & $42.63 \mathrm{MPa}$ \\
\hline H-shaped steel & $203 \mathrm{GPa}$ & $215 \mathrm{MPa}$ & $335 \mathrm{MPa}$ & - & - & - \\
\hline
\end{tabular}

Note. $E_{\mathrm{s}}$ represents the hot-rolled H-beam elastic modulus; $\sigma_{\mathrm{sy}}$ represents the yield strength of the hot-rolled H-beam; $\sigma_{\text {su }}$ represents the limit strength of the hot-rolled H-beam; $E$ represents the elastic modulus of deciduous larch wood; $f_{\mathrm{m}}$ represents the flexural strength of deciduous larch; $f_{\mathrm{c}}$ represents the compressive strength of deciduous larch.
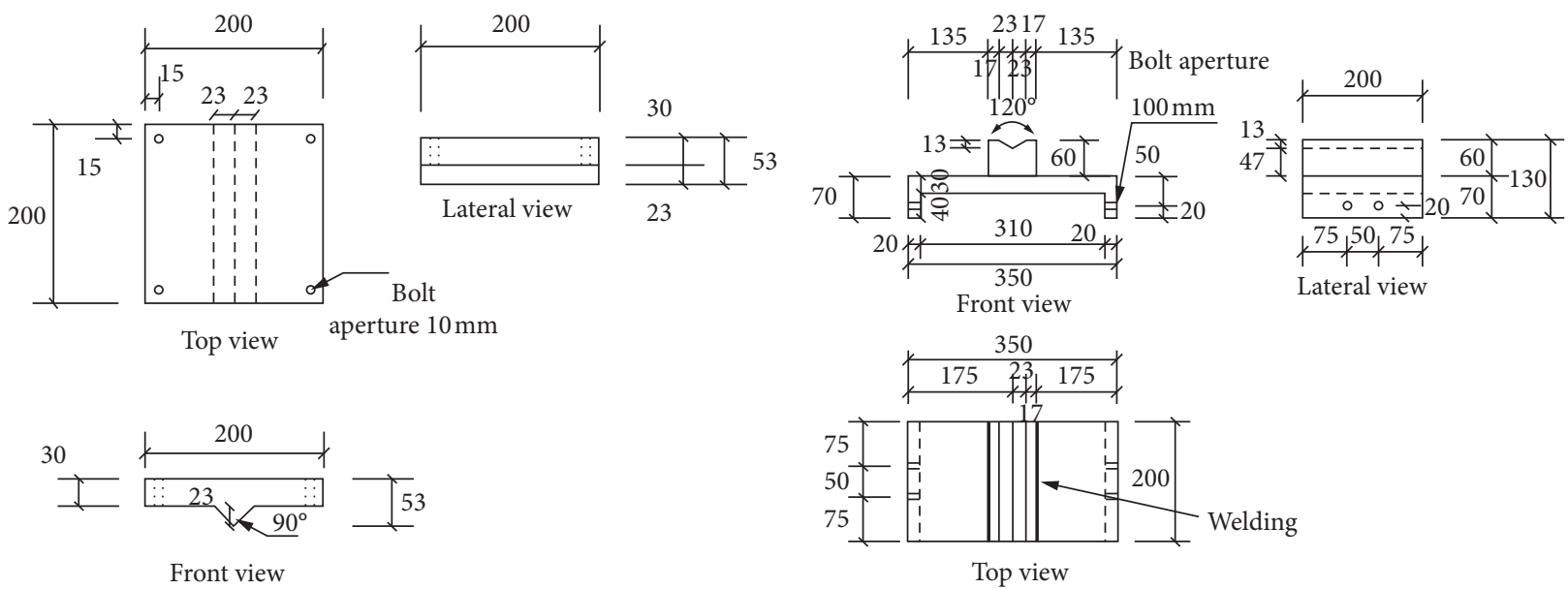

(a)

(b)

(c)

FIGURE 5: The unidirectional cutter-reamer support: (a) design drawing of the upper part of unidirectional hinge bearing; (b) design drawing for the lower part of unidirectional hinge bearing; (c) finished product.

same displacement was also increased sharply. As the load began to increase rapidly, the test piece continuously emitted frequently and loud humming sound. The strain on the compressive side of some composite columns was increased sharply. And at the same time, the angle of the one-way tool hinge support became large until a loud bang was heard. The larch wood board with corbels on the composite columns was broke, and the specimens lost their 


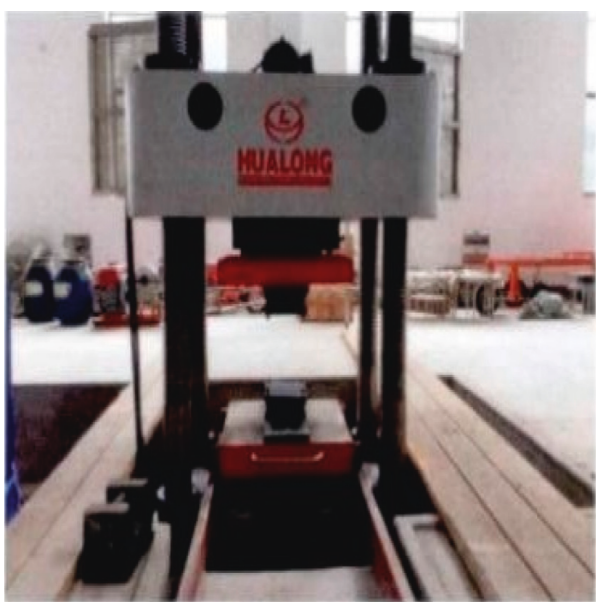

(a)

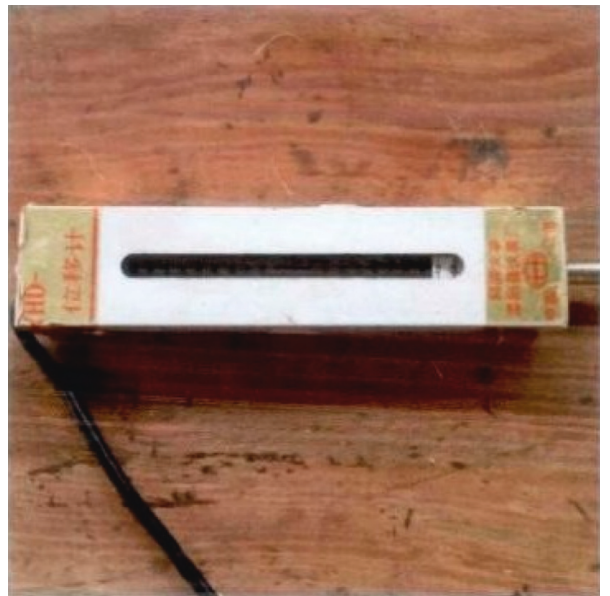

(c)

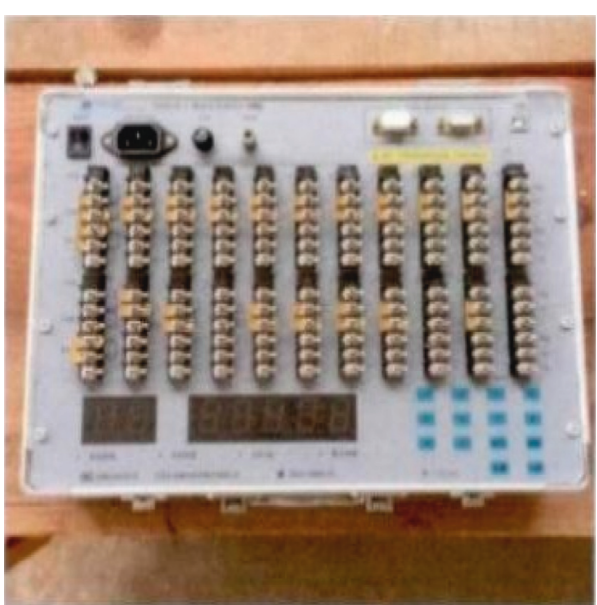

(b)

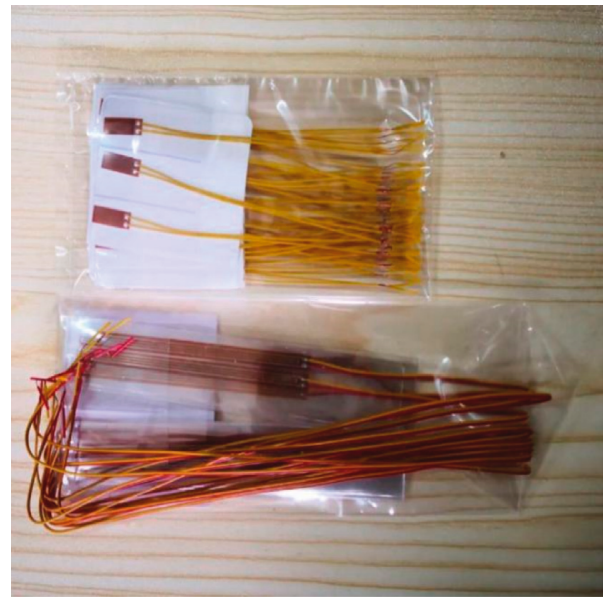

Figure 6: Experiment equipment and device: (a) electrohydraulic servo pressure testing machine controlled by a microcomputer; (b) static strain tester; (c) displacement sensor; (d) resistance strain gauge.

TABLE 3: Resistance strain gauge technical parameters.

\begin{tabular}{lcccc}
\hline Model & Resistance & Sensitivity coefficient & Gate length $\times$ width & Accuracy level \\
\hline BX120-80AA & 120 & $2.0 \pm 1 \%$ & $80 \times 3 \mathrm{~mm}$ & A \\
BX120-10AA & 120 & $2.0 \pm 1 \%$ & $10 \times 3 \mathrm{~mm}$ & A \\
\hline
\end{tabular}

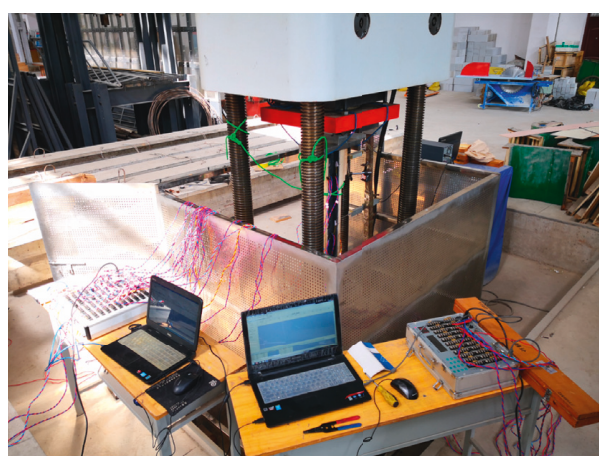

(a)

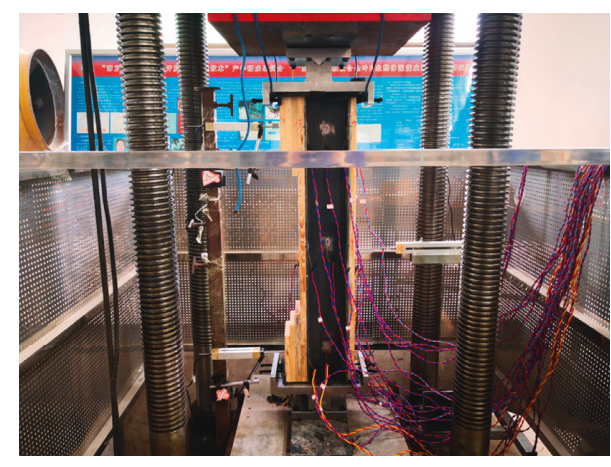

(b)

Figure 7: Test site. 


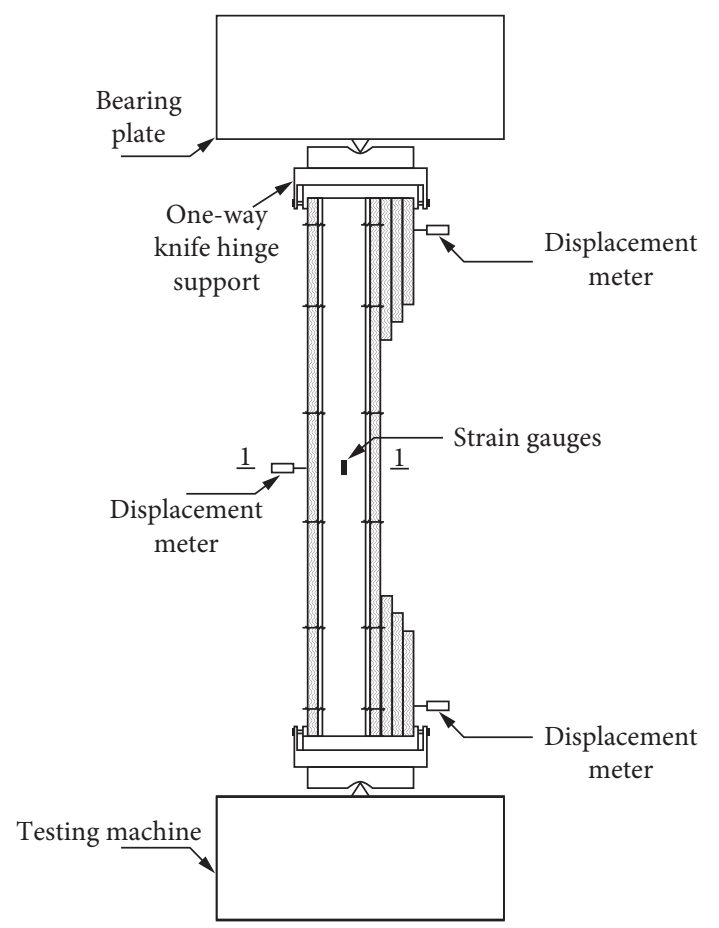

Figure 8: Displacement meter layout.

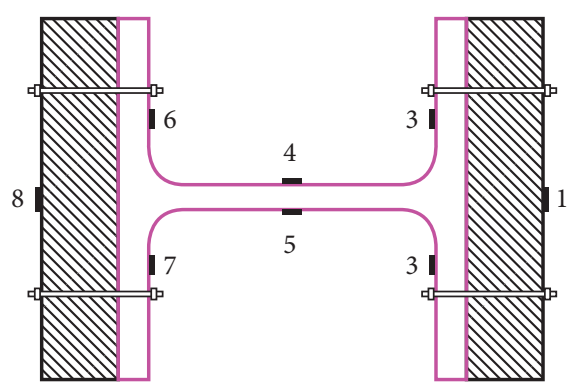

FIGURE 9: Strain gauge layout.

bearing capacity. The failure phenomena are shown in Figures 11(a)-11(d).

\section{Analysis of Test Results}

4.1. Strain Analysis. The load-strain curves of type A composite columns are shown in Figure 12. As shown in Figure 9, the strain values of the larch board were measured at points 1 and 8 , while the strain values of the hot-rolled $\mathrm{H}$-beam were measured at points 2 to 7 . According to the load-strain curves of the four A-type composite columns in Figure 12, it can be seen that the strain of A-type composite columns all grew linearly at the initial stage of loading. The increasing rates of strain were relatively at a same level; however, the No. 1 measuring point grew faster than other samples. This trend could be explained that the one-way cutter hinge support was used in the test, and the larch board of the No. 1 measuring point was near to eccentricity and bore more pressure. In the midloading stage, the load-strain line increased linearly, indicating that the composite columns were still at the elastic stage. However, a phenomenon of strain mutation could also been observed. This trend could be explained that the structural adhesive bonding was used in the A-type composite, which hindered the integrity of the specimen. Therefore, when the load was about $70 \mathrm{kN}$, different degrees of the glue breaking phenomenon between the larch board and hot-rolled H-section steel occurred, resulting in redistributing of the stress. Therefore, a strain mutation could be observed. The stress changes at points $2-7$ were almost the same, while the strain changes at points 1 and 8 were obvious. The variation of the strain change could be attributed to that the compressive modulus of the hot-rolled H-beam was ten times more than that of the larch board. Therefore, the larch board needed more strain under the same stress. Moreover, bending moment generated by the initial eccentricity of the composite column at $30 \mathrm{~mm}$ did not play a control role in the case of small load, and the specimen tended to be vertically compressed and expanded under the action of axial force. Although the larch board bended in the composite column, no damage was obtained by the hot-rolled H-beam and the larch board in the later stage of loading. From the loading curve, the specimen was still at the elastic stage. However, with the increase of load, the glue opening phenomenon on the cementing surface presented an expanding trend. Finally, the larch board was separated from the hot-rolled H-beam, which results in the loss of the load-carrying capacity of the specimens.

The load-strain curves of B-type composite columns are shown in Figure 13. The load-strain curves of Z-5, Z-6, Z-7, and Z-8 are arranged from left to right. As shown in Figure 13, the strains corresponding to the four sides of the B-type composite column was increased linearly at their respective speeds in the initial stage of loading. The strains at point 1 and point 8 were increased faster than that of other measuring points. The reason for this trend was the same as that of the A-type composite column. Furthermore, the whole workability of the specimen was improved, and the stiffness of the specimen was increased after being anchored with bolts. As a result, the No. 8 test point was under certain pressure. The specimen was more inclined to axial compression when the initial load strength was not high. In the middle stage of loading, the strain mutations occurred at No. 1 and No. 8 of the B-type composite column. The reason is that the main bearing object of axial force changed from the larch board to $\mathrm{H}$-section steel. At this time, the section steel presented elastic deformation; however, the larch board began to present plastic deformation. At the later stage of loading, the specimens generally entered the plastic deformation stage and the second-order effect of bending moment occurred. When the load approached the ultimate value, the larch board with brackets on the left side reached the ultimate strength and ruptured. It is worthy mentioning that the strain values of the larch board at points 1 and 8 on the left side of B-type composite columns were generally much larger than those at the top of hot-rolled $\mathrm{H}$-section steel. Moreover, the flanges of the upper and lower ends of hotrolled $\mathrm{H}$-section steel also reached the yield strength. During the whole loading process, the strength of both materials was 


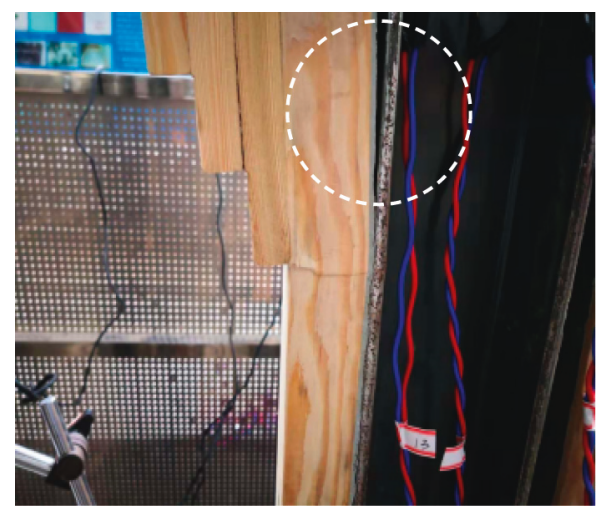

(a)

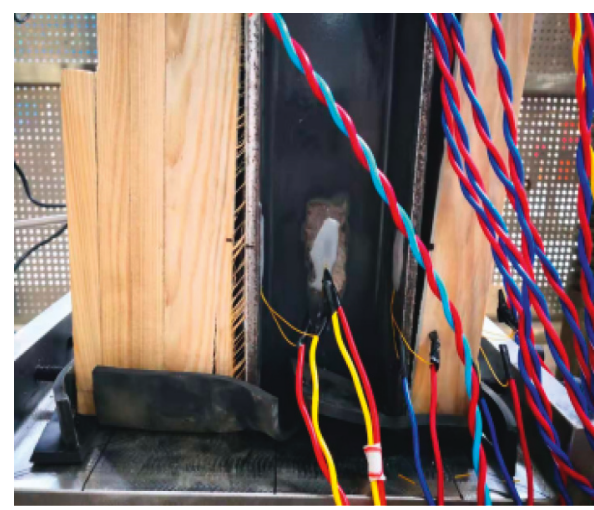

(c)

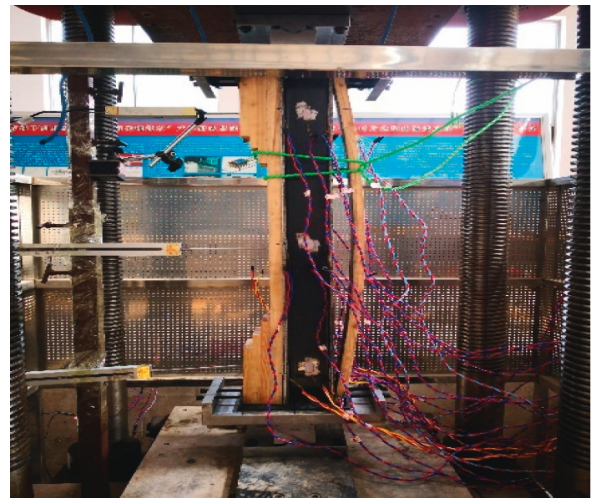

(e)

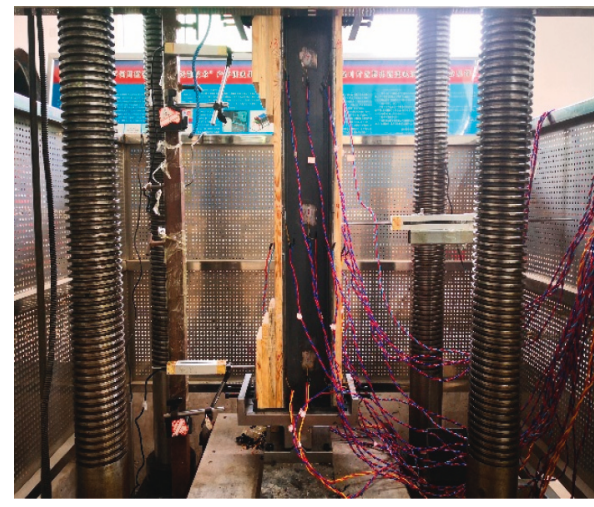

(g)

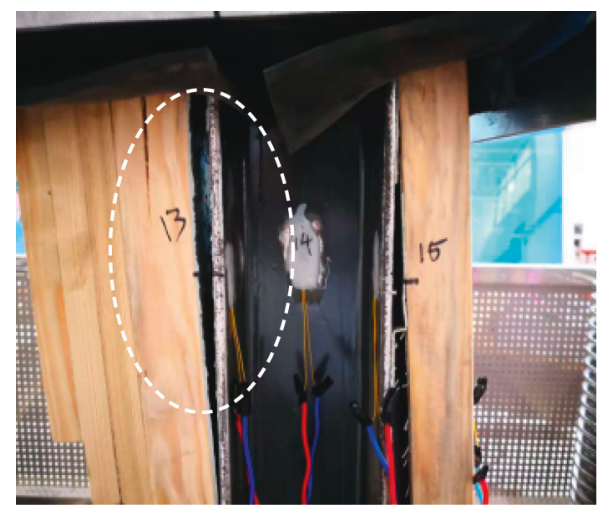

(b)

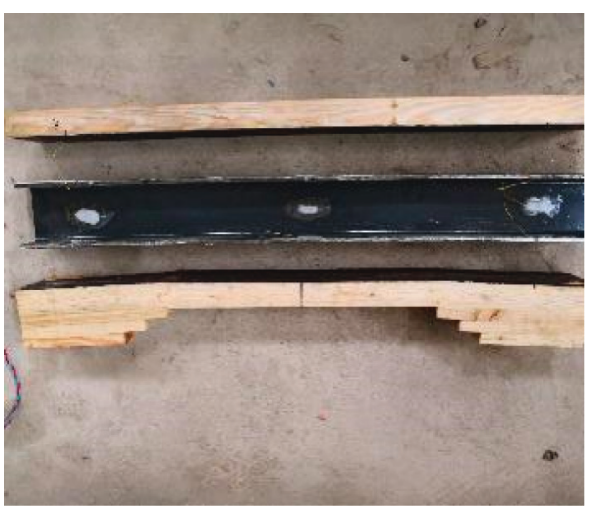

(d)

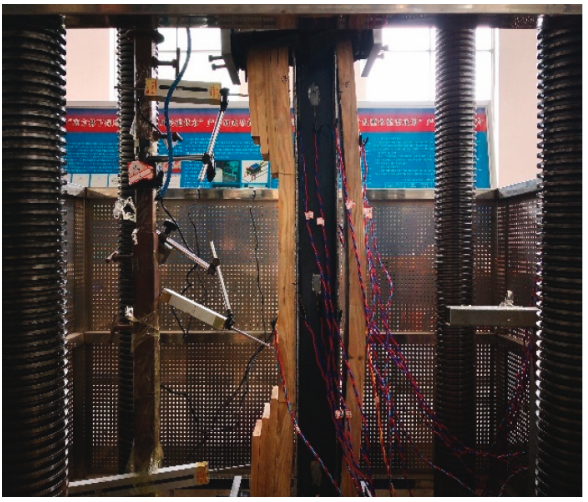

(f)

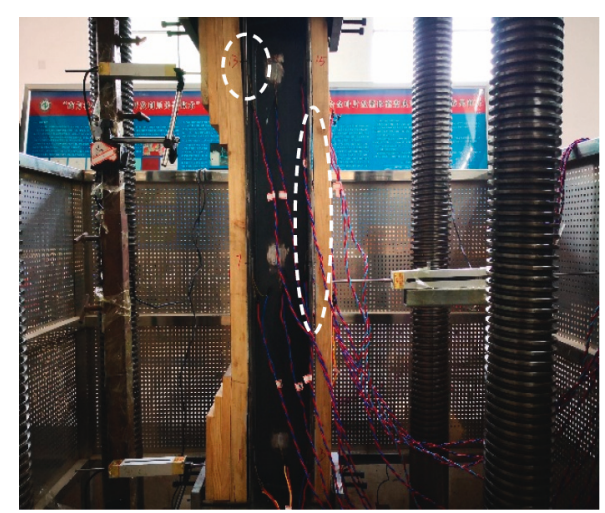

(h)

FIGURE 10: Failure phenomena of class A specimens: (a) creasing phenomenon; (b) the upper end appears to open; (c) the lower end appears to open; (d) completely unglued specimen; (e) specimen Z-1; (f) specimen Z-2; (g) specimen Z-3; (h) specimen Z-4. 

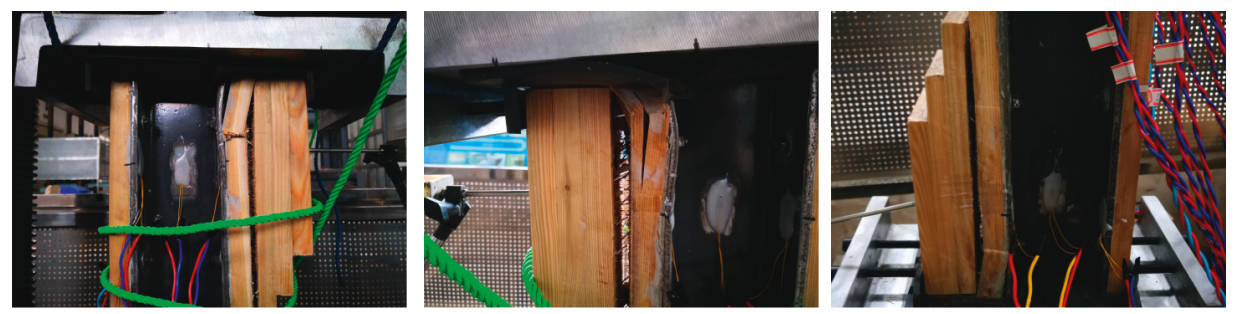

(a)
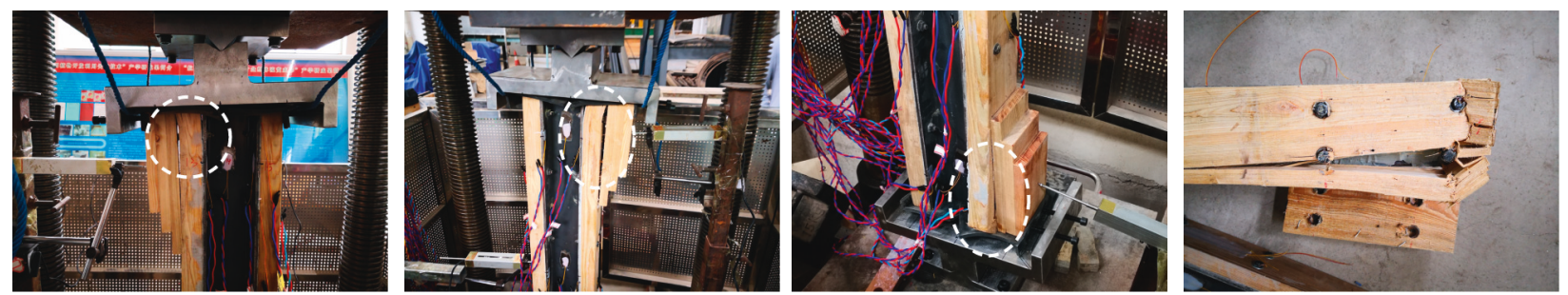

(b)
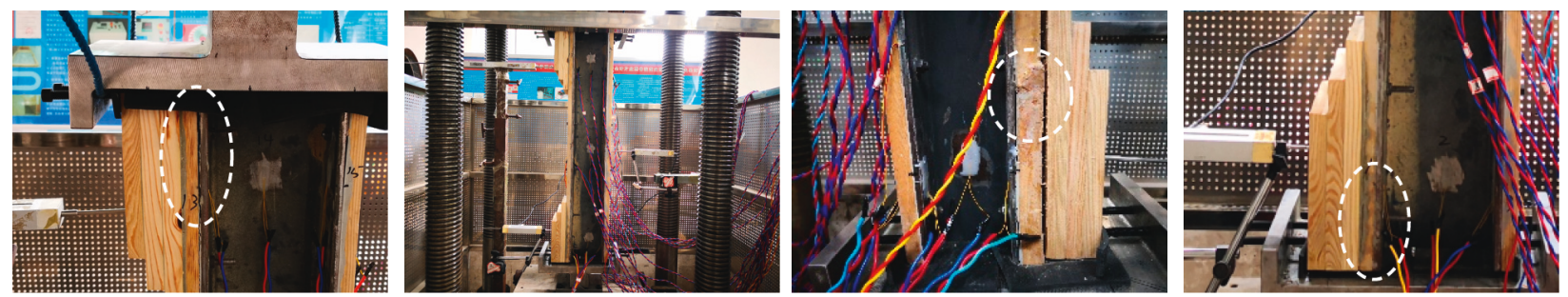

(c)
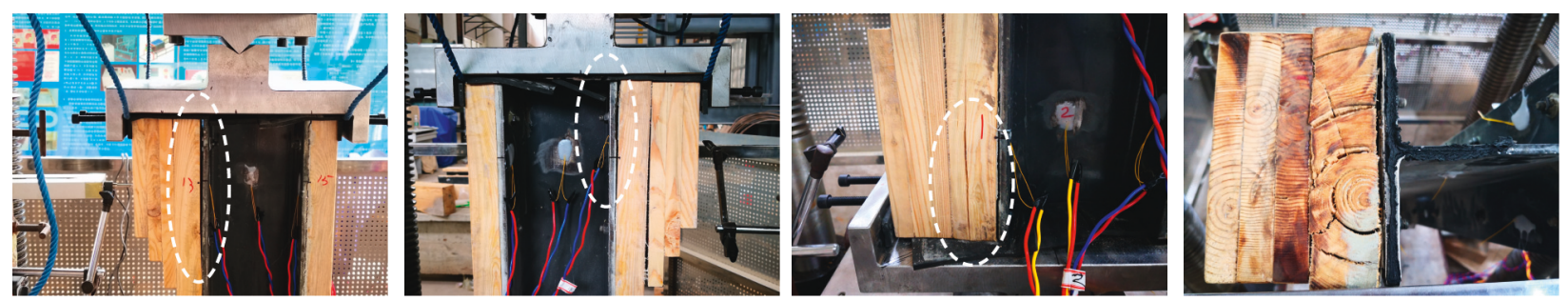

(d)

Figure 11: Failure phenomena of type B specimens: (a) specimen Z-5; (b) specimen Z-6; (c) specimen Z-7; (d) specimen Z-8.

well developed and the strain of the larch wood plate was always greater than that of hot-rolled H-section steel. It can be concluded that the combination effect of structural glue and bolt is very good for the larch board and hot-rolled H-beam. The overall working performance of composite columns under load is excellent, and the bearing capacity of B-type composite columns is obviously higher than that of A-type composite columns.

4.2. Load-Deflection and Bearing Capacity Analysis. The load-deflection curve of type A composite columns is shown in Figure 14. The regularity of deflection of the A-type composite column with the increase of the load could be easily identified. In the initial stage of loading, the larch board in the composite column worked in coordination with the hot-rolled H-beam, and the deflection value of the composite column increased linearly with the increase of load. In the middle stage of loading, the A-type specimens were still in the elastic stage; however, the slope of loaddeflection curves of four specimens changed when the load reached from $60 \mathrm{kN}$ to $100 \mathrm{kN}$. This trend could explain that the appearance of glue opening leads to a rapid increase of deformation with the increase of the load value. In the later stage of loading, the structural glue between the larch board and the hot-rolled $\mathrm{H}$-section steel unglued completely, and the larch board on the nonbracket side suddenly bulged outwards and no longer formed the composite column structure. Therefore, a sharp increase of deformation could be also found. Furthermore, the hot-rolled $\mathrm{H}$-section steel and larch board did not reach the ultimate load and no obvious damage could be identified, so the failure mode of the specimen was instability failure.

The maximum deflection value $\left(\delta_{\max }\right)$ and the corresponding load value $\left(P_{\mathrm{u}}\right)$ of A-type composite column specimens are shown in Table 4 . Combined with Figure 14 and Table 4, it is concluded that the bearing capacity of members increased with increasing wood 


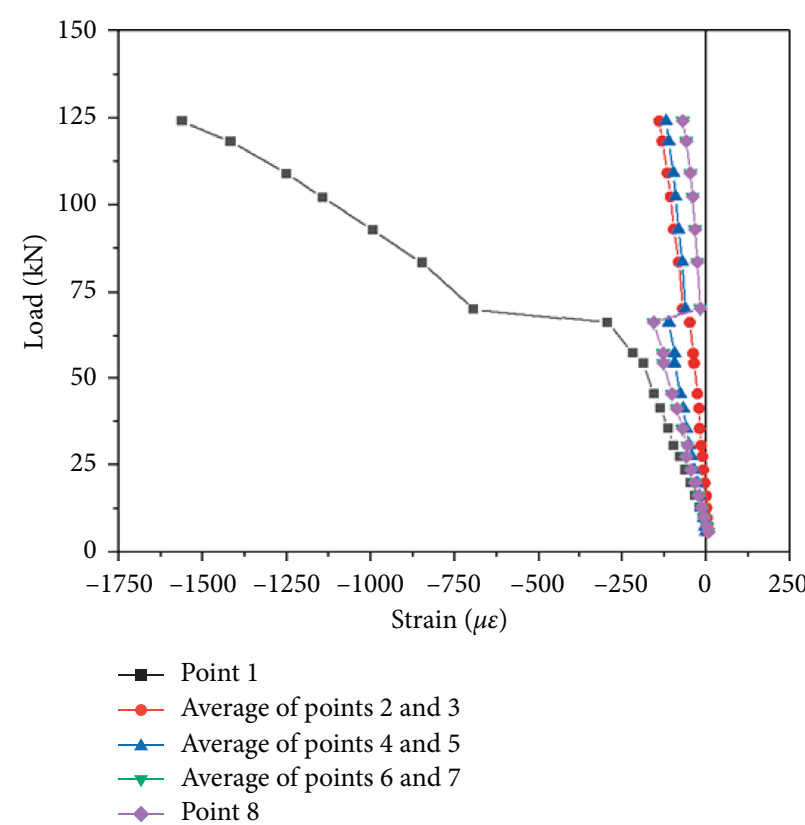

(a)

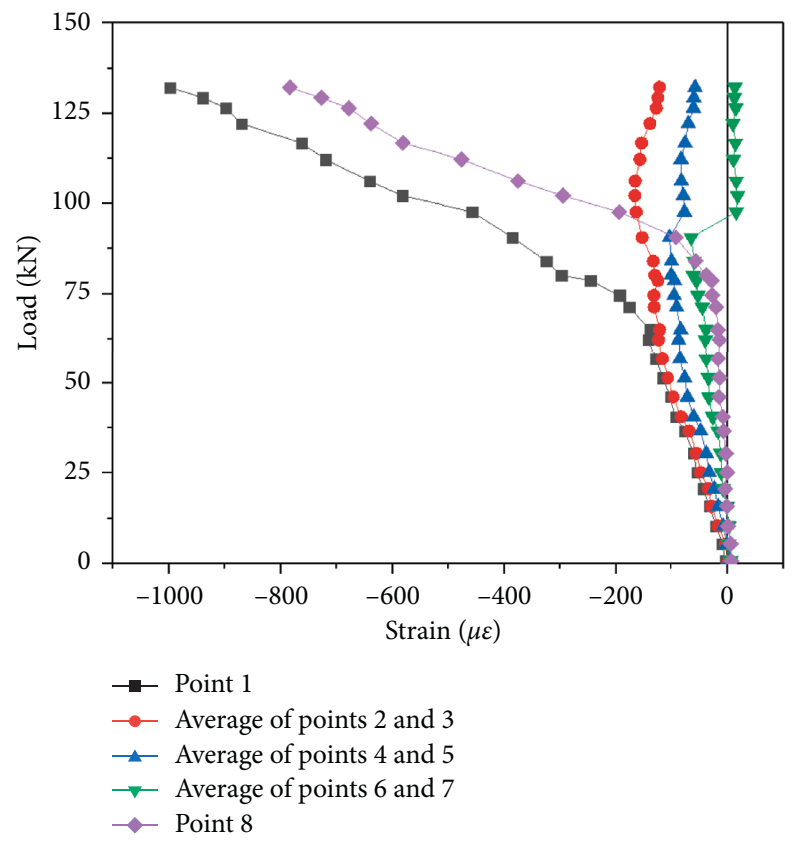

(c)

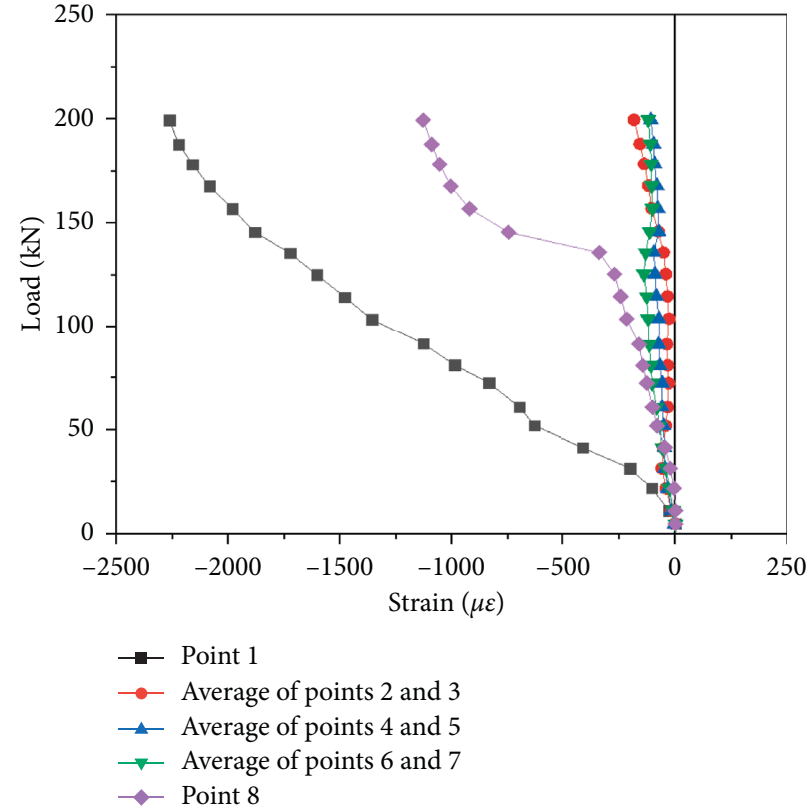

(b)

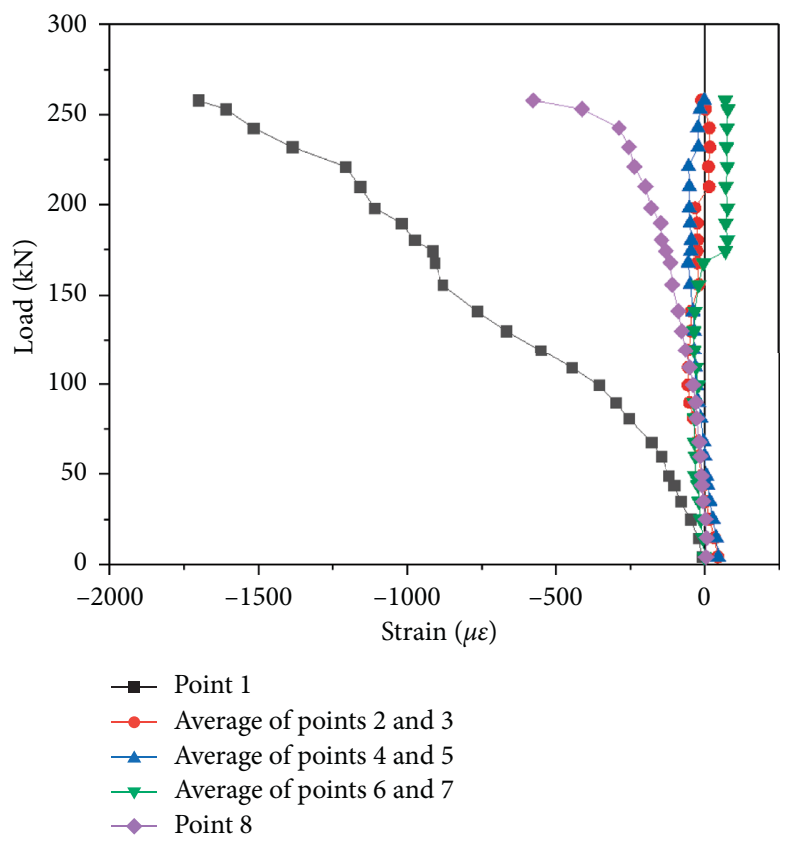

(d)

Figure 12: Load-strain curves of class A composite columns: (a) Z-1; (b) Z-2; (c) Z-3; (d) Z-4.

thickness and cross-sectional area of the hot-rolled H-beam in A-type composite columns. It should be noted that the deflection value was mainly affected by the thickness of larch wood.

The load-deflection curve of the B-type specimen Z5-Z8 is shown in Figure 15. At the initial stage of loading, the specimen was at the elastic stage. The larch board in the composite column worked with $\mathrm{H}$-section steel, and its deformation increased linearly with the increase of load. At the middle stage of loading, the deformation of composite columns increased rapidly with the increase of the load value after the specimen changed into the elastic-plastic stage. At the later stage of loading, the larch board with brackets on the left side of the specimen was crushed at the ultimate load. However, the specimen did not fail immediately, and the steel-wood composite columns exhibited ductile failure.

The maximum deflection value $\delta_{\max }$ of all type $\mathrm{B}$ composite column specimens and the corresponding load value $P_{\mathrm{u}}$ is listed in Table 5. The increase of deflection of B-type composite columns was mainly affected by the area of the hot-rolled H-beam. When the area of the hot-rolled 


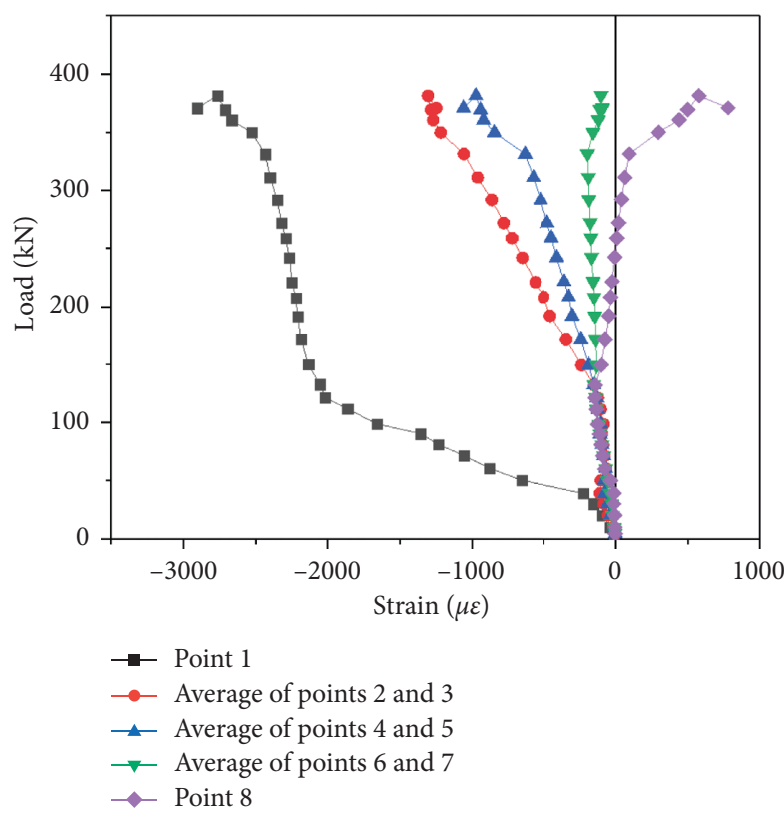

(a)

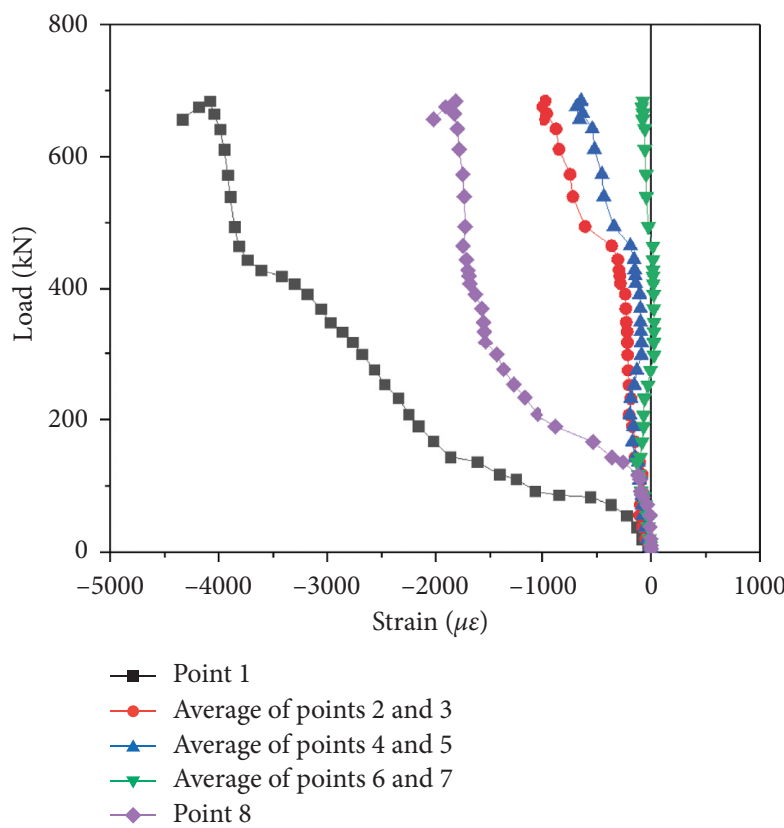

(c)

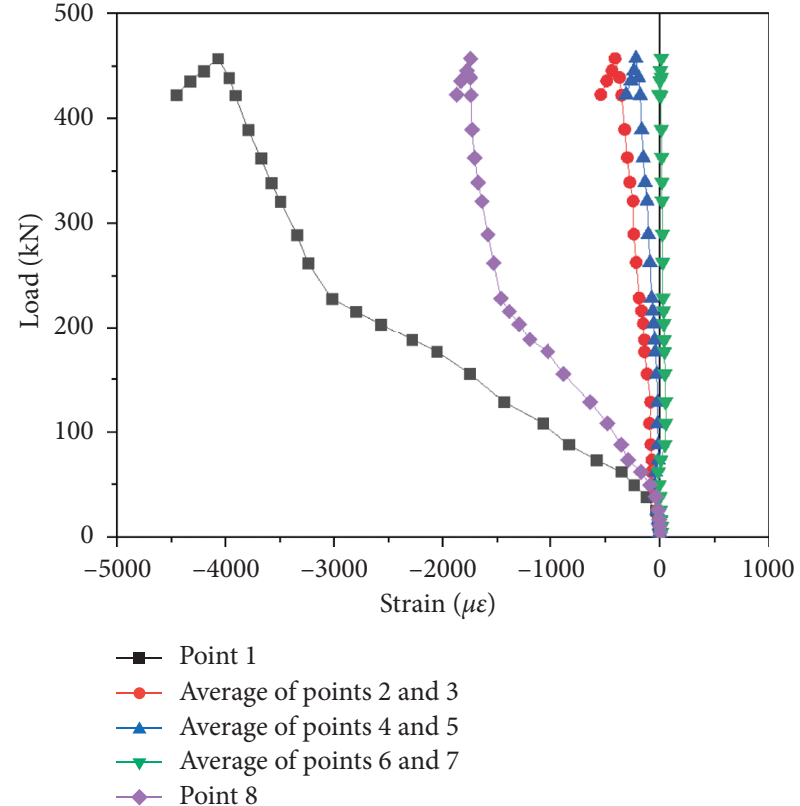

(b)

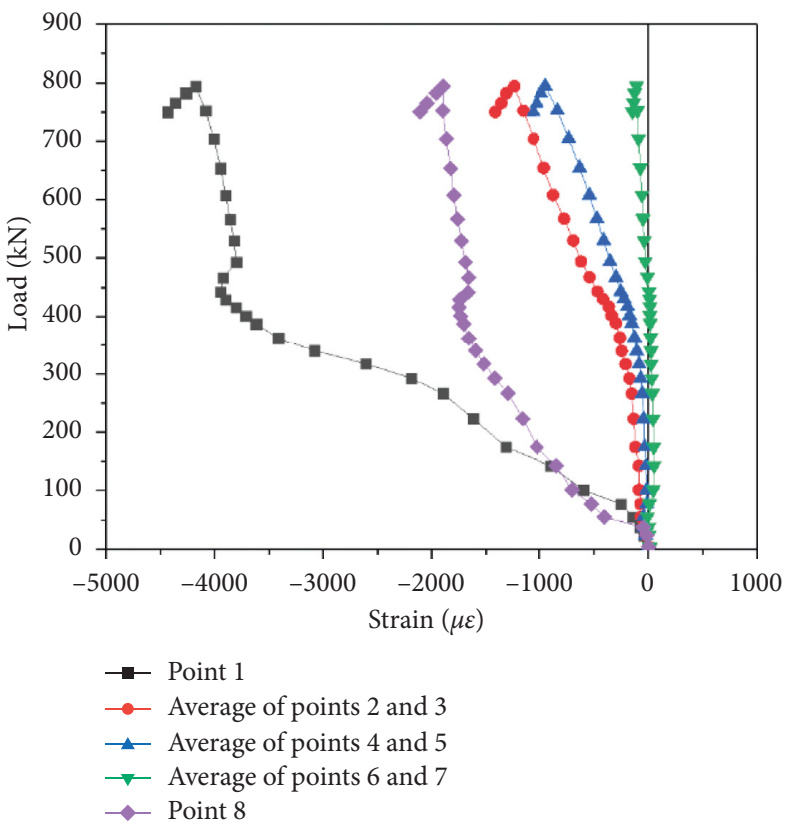

(d)

Figure 13: Load-strain curves of type B composite columns: (a) Z-5; (b) Z-6; (c) Z-7; (d) Z-8.

H-beam was the same, the deflection of composite columns was almost the same. However, the ultimate deflection of the composite columns with a smaller area of the hot-rolled H-beam was greater than that of a larger one.

4.3. Stability Comparison with Hot-Rolled H-Beam. Referring to the "Steel Structure Design Standard" GB50017-2017, the stability of the B-type composite column was compared with that of the pure steel column for further study. The stability formula can be expressed as follows:

$$
\begin{aligned}
\frac{N}{\varphi_{\mathrm{X}} A}+\frac{\beta_{\mathrm{m}} N e}{\gamma W\left(1-\left(0.8 N / N_{\mathrm{ex}}\right)\right)} & \leq f, \\
N_{\mathrm{ex}} & =\frac{\pi^{2} E A}{\left(1.1 \lambda^{2}\right)},
\end{aligned}
$$

where $N$ is the pressure design value $(\mathrm{kN}) ; \varphi_{\mathrm{X}}$ is the stability coefficient of axial compression in the bending moment action plane, and the value is $0.924 ; A$ is the sectional area $\left(\mathrm{mm}^{2}\right) ; \beta_{\mathrm{m}}$ is the equivalent moment coefficient, and the value is $1.0 ; e$ is the eccentricity $(\mathrm{mm}) ; W$ is the modulus of 


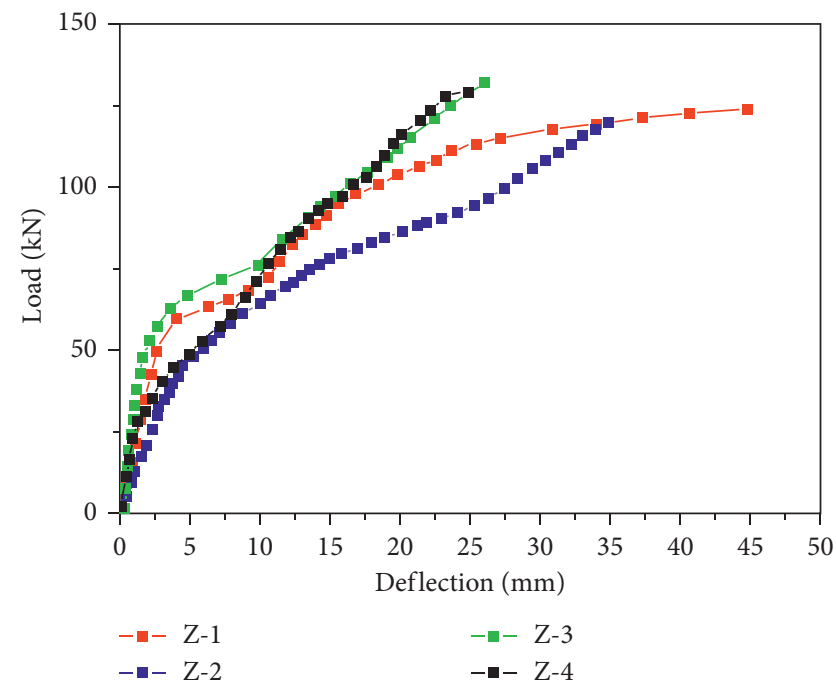

Figure 14: Load-deflection curves of Z-1 to Z-4.

TABle 4: Test results of class A composite columns.

\begin{tabular}{lcc}
\hline $\begin{array}{l}\text { Specimen } \\
\text { number }\end{array}$ & $\begin{array}{c}\text { Maximum deflection } \delta_{\max } \\
(\mathrm{mm})\end{array}$ & $\begin{array}{c}\text { Ultimate load } P_{\mathrm{u}} \\
(\mathrm{kN})\end{array}$ \\
\hline $\mathrm{Z}-1$ & 44.75 & 123.97 \\
$\mathrm{Z}-2$ & 33.82 & 199.77 \\
$\mathrm{Z}-3$ & 24.56 & 132.2 \\
$\mathrm{Z}-4$ & 22.14 & 258.07 \\
\hline
\end{tabular}

Note: $P_{\mathrm{u}}$ represents the maximum stress of the specimen. $\delta_{\max }$ represents the maximum deflection of the specimen.

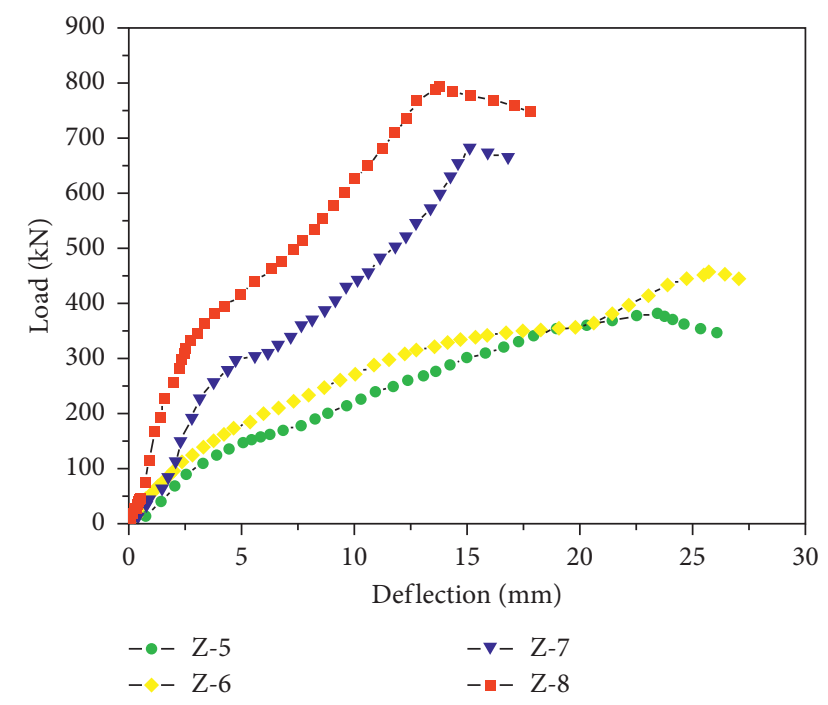

Figure 15: Load-deflection curves of Z-5 to Z-8.

TABLe 5: Test results of type B composite columns.

\begin{tabular}{lcc}
\hline Specimen number & $\delta_{\max }(\mathrm{mm})$ & $P_{\mathrm{u}}(\mathrm{kN})$ \\
\hline Z-5 & 26.05 & 381.56 \\
Z-6 & 27.00 & 457.38 \\
Z-7 & 16.78 & 682.40 \\
Z-8 & 17.79 & 794.78 \\
\hline
\end{tabular}

Note: $P_{\mathrm{u}}$ represents the maximum stress of the specimen. $\delta_{\max }$ represents the maximum deflection of the specimen. the compressed section in the moment action plane $\left(\mathrm{mm}^{3}\right) ; \gamma$ is the plastic development coefficient of section, and the value is $1.05 ; \lambda$ is the slenderness ratio of components.

From Table 6, it can be concluded that the combination column could effectively improve the stability of H-type steel.

\section{Analysis of Influencing Factors on Bearing Capacity of Composite Columns}

5.1. Combining Form. The A-type composite columns were bonded with the larch board and hot-rolled H-section steel only by structural bonding. From the analysis of the previous section, the bearing capacity during the experiment was much smaller than that of the B-type composite columns bonded with both structural rubber and bolt anchoring. Neither the larch board nor the hot-rolled H-section steel in the composite columns was damaged due to the instability failure of type A composite columns. However, for B-type composite columns, the glue opening phenomenon and the integrity/bearing capacity of composite columns were in favor to improve the bolt anchorage; compared with A-type composite columns, the bearing capacity of B-type composite columns increased by $240.23 \%$ on average and the deflection decreased by $9.42 \mathrm{~mm}$ (Table 7 ).

5.2. Change of Wood Thickness. Under the same eccentricity and cross-sectional area of hot-rolled $\mathrm{H}$-section steel, the thickness of larch wood increased from $20 \mathrm{~mm}$ to $40 \mathrm{~mm}$ and the bearing capacity of composite columns increased by $19.9 \%$ to $75.82 \mathrm{kN}$ (as shown in Figure 15 and Table 5).

Moreover, the thickness of larch wood varied from $20 \mathrm{~mm}$ to $40 \mathrm{~mm}$ and the bearing capacity increased by $16.47 \%$ to $112.38 \mathrm{kN}$.

The lateral deflection of specimens Z-7 and Z-8 under various loads is shown in Figure 16. With the increasing section size, the resistance to bending deformation of the specimen was enhanced. The deflection change process showed certain ductility characteristics.

For type B composite columns with a larger cross-sectional area, it was easier for larch boards to bulge out under small eccentricity. As a result, the ultimate deflection of the composite column became larger. However, the deflection increased less than $1 \mathrm{~mm}$ when the bearing capacity increased by $112.38 \mathrm{kN}$. The improvement of bearing capacity and stability can be attributed to the change of the thickness of larch boards.

5.3. Change of Section Area. According to Figure 15 and results of Z-5 and Z-7, the bearing capacity could be improved with the increasing cross-sectional area of steel-wood composite columns. The thickness of the larch board of Z-5 and Z-7 specimens was $20 \mathrm{~mm}$, but the core of the Z-5 composite column was hot-rolled $\mathrm{H}$-section steel with an area of $100 \times 100^{2} \mathrm{~mm}$, while the Z-7 composite column was hot-rolled H-section steel with an area of $150 \times 150 \mathrm{~mm}^{2}$. The bearing capacity of the Z-7 composite column increased 
TABLE 6: Stability analysis.

\begin{tabular}{lcc}
\hline Specimen number & $P_{\mathrm{u}}(\mathrm{kN})$ & $\begin{array}{c}\text { Ultimate bearing capacity of the hot-rolled H-beam } \\
(\mathrm{kN})\end{array}$ \\
\hline $\mathrm{Z}-5$ & 381.56 & 381 \\
$\mathrm{Z}-6$ & 457.38 & 673 \\
$\mathrm{Z}-7$ & 682.40 & \\
$\mathrm{Z}-8$ & 794.78 & \\
\hline
\end{tabular}

Note: $P_{\mathrm{u}}$ represents the maximum stress of the specimen.

TABLE 7: Contrast results of different combinations.

\begin{tabular}{|c|c|c|c|c|c|}
\hline $\begin{array}{l}\text { Contrast } \\
\text { group }\end{array}$ & $\begin{array}{l}\text { Specimen } \\
\text { number }\end{array}$ & Ultimate bearing capacity $P_{\mathrm{u}}(\mathrm{kN})$ & Maximum deflection $\delta_{\max }(\mathrm{mm})$ & $\begin{array}{l}\text { Increasing rate of bearing } \\
\text { capacity }(\%)\end{array}$ & $\begin{array}{l}\text { Deflection } \\
\text { reduction }\end{array}$ \\
\hline \multirow{2}{*}{1} & Z-1 & 123.97 & 44.75 & \multirow{2}{*}{207.8} & \multirow{2}{*}{$18.7 \mathrm{~mm}$} \\
\hline & Z-5 & 381.56 & 26.05 & & \\
\hline \multirow{2}{*}{2} & Z-2 & 199.77 & 33.82 & \multirow{2}{*}{128.95} & \multirow{2}{*}{$6.82 \mathrm{~mm}$} \\
\hline & Z-6 & 457.38 & 27.00 & & \\
\hline \multirow{2}{*}{3} & Z-3 & 132.2 & 24.56 & \multirow{2}{*}{416.18} & \multirow{2}{*}{$7.78 \mathrm{~mm}$} \\
\hline & Z-7 & 682.40 & 16.78 & & \\
\hline \multirow{2}{*}{4} & Z-4 & 258.07 & 22.14 & \multirow{2}{*}{207.97} & \multirow{2}{*}{$4.35 \mathrm{~mm}$} \\
\hline & Z-8 & 794.78 & 17.79 & & \\
\hline
\end{tabular}

Note: $P_{\mathrm{u}}$ represents the maximum stress of the specimen. $\delta_{\max }$ represents the maximum deflection of the specimen.

by $300.84 \mathrm{kN}$. The test results of specimens Z- 6 and Z-8 also showed that the bearing capacity of hot-rolled $\mathrm{H}$-section steel Z-8 with a larger cross-sectional area was $337.4 \mathrm{kN}$ more than that of Z- 6 . Therefore, it can be concluded that the section area of $\mathrm{H}$-section steel used in this composite column had a great influence on its bearing capacity. The deflection increase gradient of Z-5 specimens under different loads was significantly greater than that of Z-7 specimens, and the ultimate deflection decreased with the increase of cross section, as shown in Figure 16. Thus, the size of the $\mathrm{H}$-section also had a significant impact on the stability of the lifting composite columns.

\section{Technical Calculation of Bearing Capacity}

Based on the above analysis, the following three ideal hypotheses were proposed for the stress process of the specimen under eccentric compression:

(1) At the initial stage of loading, the strain of the hotrolled H-section steel is basically the same as that of larch wood, the overall mechanical performance is good, and the specimen is in the linear elastic stage.

(2) With the increasing load, the larch board reaches the plastic stage first, while the hot-rolled $\mathrm{H}$-section steel is still in the linear elastic stage. When the larch board enters into the plastic stage, the strengthening effect is weak, and the increasing load is almost borne by the hot-rolled H-beam. The deformation difference between the two materials is increasing. When the interfacial stress reaches the strength of the adhesive, the interfacial bonding failure will occur. However, the specimen can continue to bear in coordination, resulting in the composite column anchored by bolts.
(3) Although the flange of the hot-rolled H-beam in composite column yields, the main cause of specimen failure is the failure of the larch board.

Based on the assumptions above, the formulas for calculating the eccentric bearing capacity of type B composite columns are derived from the simple superposition principle as follows:

$$
\begin{aligned}
& P_{\mathrm{u}}=\varphi_{\mathrm{l}} \varphi_{\mathrm{a}} \varphi_{\mathrm{e}}\left(P_{\mathrm{C}}+P_{\mathrm{S}}\right), \\
& P_{\mathrm{c}}=f_{\mathrm{c}} A_{\mathrm{c}}, \\
& P_{\mathrm{s}}=f_{\mathrm{sy}} A_{\mathrm{s}} .
\end{aligned}
$$

where $P_{\mathrm{u}}$ is the eccentric compressive bearing capacity of the specimen; $P_{\mathrm{c}}$ and $P_{\mathrm{s}}$ are the compressive bearing capacity of the larch board and hot-rolled $\mathrm{H}$-section steel in the composite column, respectively; $\varphi_{1}$ is the influence coefficient of the slenderness ratio; $\varphi_{\mathrm{a}}$ is the stability coefficient of axial compression; $\varphi_{\mathrm{e}}$ is the lateral stability coefficient of bending members; $f_{\mathrm{c}}$ is the compressive strength along the grain of larch wood; $A_{c}$ is the area of larch board; $f_{\text {sy }}$ is the yield strength of steel; $A_{\mathrm{s}}$ is the cross-sectional area of hotrolled $\mathrm{H}$-section steel.

The values of the stability factor of $\varphi_{\mathrm{a}}$ under axial compression are determined by the following formulas:

$$
\begin{aligned}
& \lambda_{\mathrm{c}}=C_{\mathrm{c}} \sqrt{\frac{\beta E_{\mathrm{k}}}{f_{\mathrm{c}}}}, \\
& \lambda=\frac{l_{0}}{i} .
\end{aligned}
$$

If $\lambda>\lambda_{\mathrm{c}}$,

$$
\varphi_{\mathrm{a}}=\frac{a_{\mathrm{c}} \pi^{2} \beta E_{\mathrm{k}}}{\lambda^{2} f_{\mathrm{c}}} .
$$




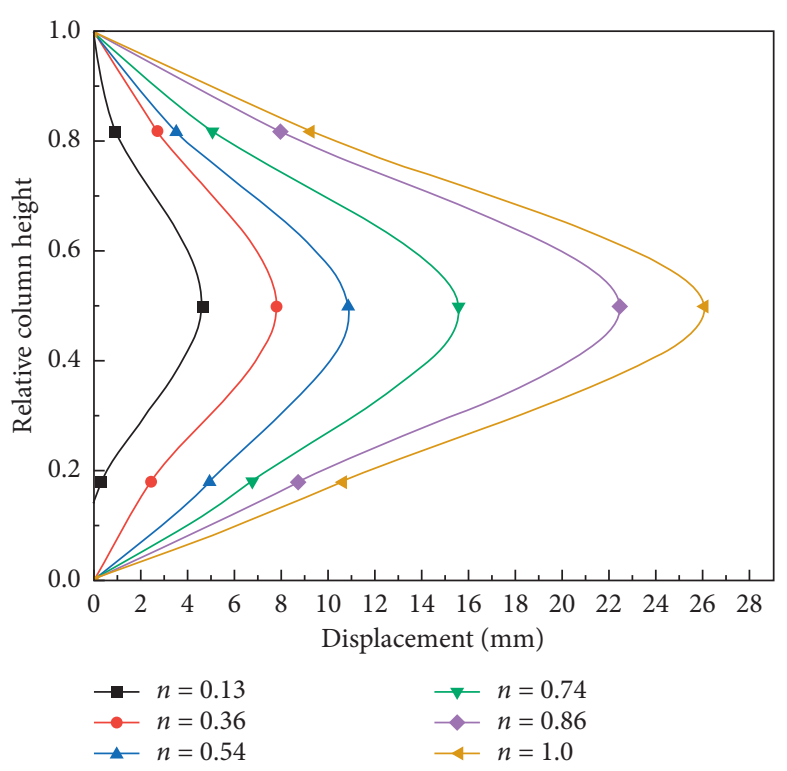

(a)

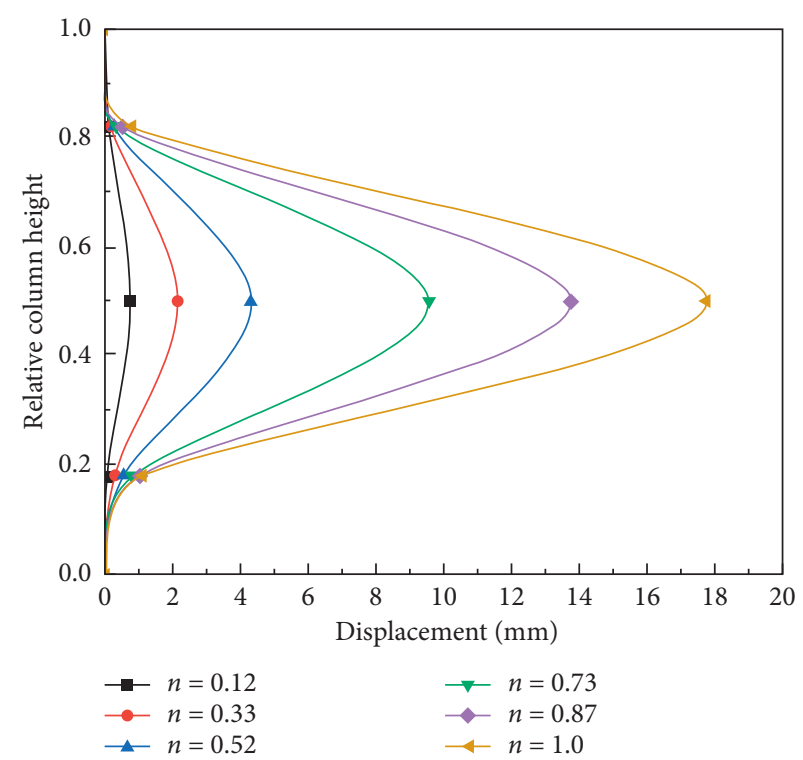

(c)

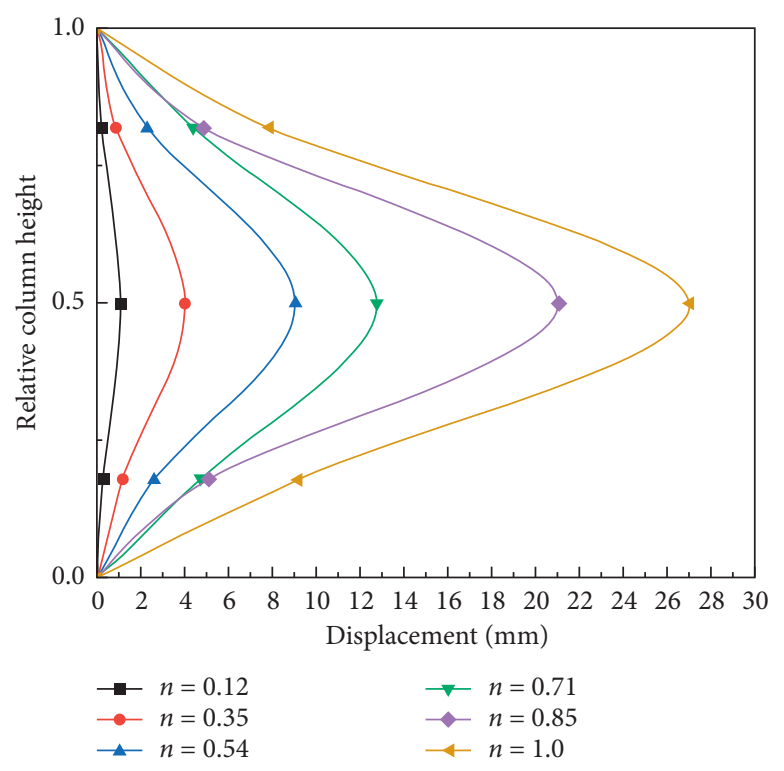

(b)

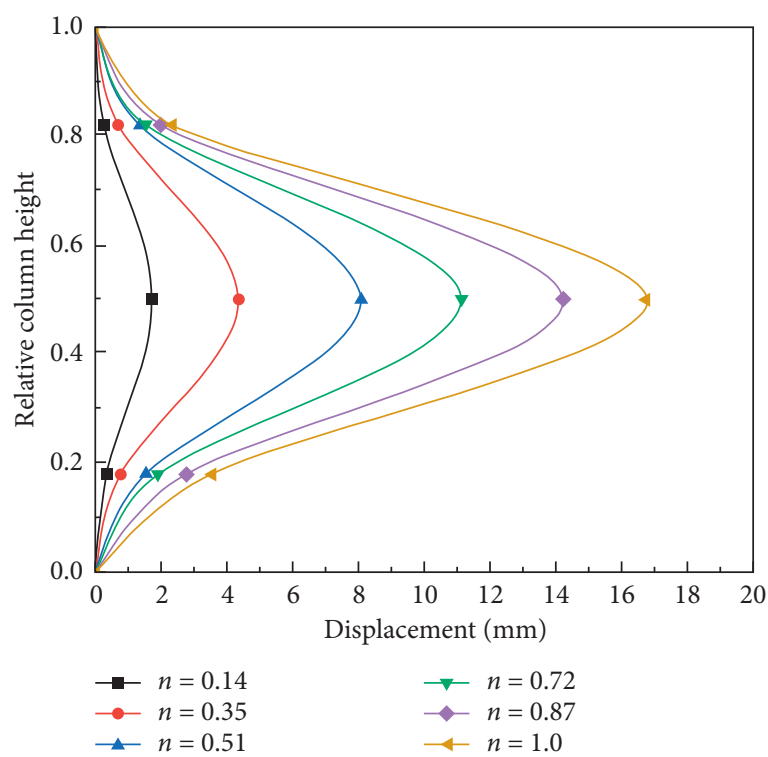

(d)

FiguRe 16: Lateral perturbation curves of specimens Z-5 and Z-8 under various loads: (a) Z-5; (b) Z-6; (c) Z-7; (d) Z-8.

If $\lambda \leq \lambda_{c}$,

$$
\varphi_{\mathrm{a}}=\frac{1}{1+\left(\left(\lambda^{2} f_{\mathrm{c}}\right) /\left(b_{\mathrm{c}} \pi^{2} \beta E_{\mathrm{k}}\right)\right)} .
$$

where $\lambda$ is the slenderness ratio of compressive members; $i$ is the rotation radius of the component section $(\mathrm{mm}) ; l_{0}$ is the calculated length of compressed members $(\mathrm{mm}) ; f_{\mathrm{c}}$ is the standard values of compressive strength of materials for compressive members $(\mathrm{MPa}) ; E_{\mathrm{k}}$ is the standard value of the elastic modulus of component materials (GPa); $a_{\mathrm{c}}, b_{\mathrm{c}}$, and $c_{\mathrm{c}}$ are $0.92,1.96$, and 4.13 , respectively, according to the book "Design Standards for Wood Structures;" and $\beta$ is the correlation coefficient of material shear deformation. Take 1.0 according to the code.
The lateral stability coefficients of $\varphi_{\mathrm{e}}$ flexural members are determined by the following formulas:

$$
\begin{aligned}
& \lambda_{\mathrm{m}}=c_{\mathrm{m}} \sqrt{\frac{\beta E_{\mathrm{k}}}{f_{\mathrm{m}}}}, \\
& \lambda_{\mathrm{B}}=\sqrt{\frac{l_{\mathrm{e}} h}{b^{2}}} .
\end{aligned}
$$

If $\lambda_{\mathrm{B}}>\lambda_{\mathrm{m}}$

$$
\varphi_{\mathrm{e}}=\frac{a_{\mathrm{m}} \beta E_{\mathrm{k}}}{\lambda_{\mathrm{B}}^{2} f_{\mathrm{m}}} .
$$

If $\lambda_{\mathrm{B}} \leq \lambda_{\mathrm{m}}$ 


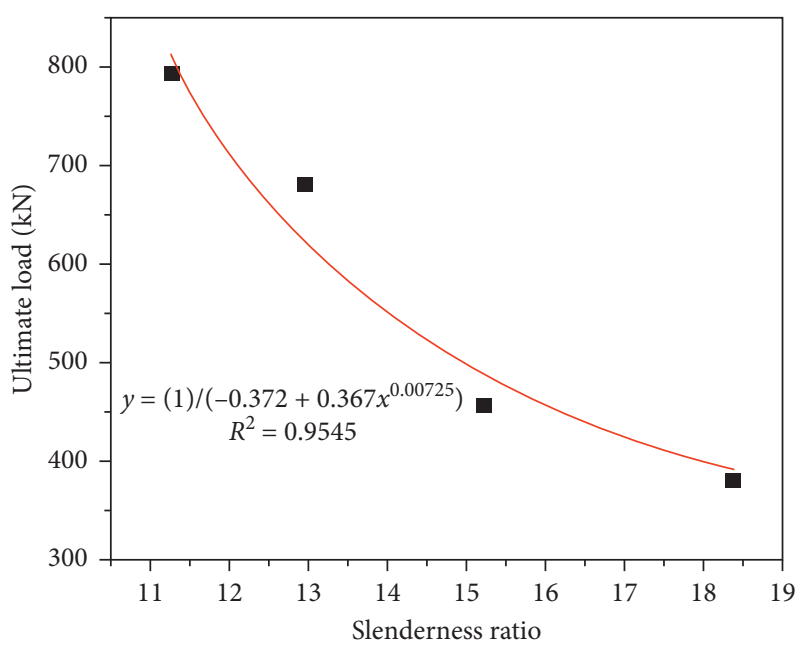

FIGURE 17: Relationship between ultimate bearing capacity and slenderness ratio.

TABLE 8: Comparison of test values and calculated values of eccentric compression columns.

\begin{tabular}{lcccc}
\hline Specimen number & Test value $P_{\mathrm{u} 1}(\mathrm{kN})$ & Calculated value $P_{\mathrm{u} 2}(\mathrm{kN})$ & Difference value $(\mathrm{kN})$ & Relative error \\
\hline Z-5 & 381.56 & 378.21 & -3.35 & $-0.88 \%$ \\
Z-6 & 457.38 & 478.76 & 21.38 & $26.60 \%$ \\
Z-7 & 682.40 & 664.93 & -17.47 & $4.67 \%$ \\
Z-8 & 794.78 & 815.75 & 20.97 & $-2.56 \%$ \\
\hline
\end{tabular}

Note: $P_{\mathrm{u} 1}$ represents the test results of specimens;. $P_{\mathrm{u} 2}$ represents the theoretical calculation results of specimens; $P_{\mathrm{c}}$ represents the bearing capacity of wood obtained by theoretical calculation.

$$
\varphi_{\mathrm{e}}=\frac{1}{1+\left(\left(\lambda_{\mathrm{B}}^{2} f_{\mathrm{m}}\right) /\left(b_{\mathrm{m}} \beta E_{\mathrm{k}}\right)\right)} .
$$

where $\lambda_{\mathrm{B}}$ is the slenderness ratio of flexural members; $b$ is the section width of bending members $(\mathrm{mm}) ; h$ is the section height of bending members $(\mathrm{mm}) ; l_{\mathrm{e}}$ is the effective length of bending members $(\mathrm{mm}) ; f_{\mathrm{m}}$ is the standard value of flexural strength of materials for flexural members $(\mathrm{MPa}) ; E_{\mathrm{k}}$ is the standard value of elastic modulus of component materials $(\mathrm{GPa}) ; a_{\mathrm{m}}, b_{\mathrm{m}}$, and $c_{\mathrm{m}}$ are $0.7,4.9$, and 0.9 , respectively, according to the book "Design Standards for Wood Structures;" and $\beta$ is the correlation coefficient of material shear deformation. Take 1.0 according to the code.

Considering the section form and size, the slenderness ratio of the B-type composite column is variable. The relationship between slenderness ratio and ultimate bearing capacity was fitted, as shown in Figure 17. A power exponential function relationship between slenderness ratio and ultimate bearing capacity can be found, whose correlation coefficient $R$ is 0.9545 , showing a high fitting correlation. The influence coefficient of the slenderness ratio is defined as $\varphi_{1}$, and its value is controlled near 1.0 according to its physical meaning. Therefore, the slenderness ratio influence coefficient $\left(\varphi_{1}\right)$ can be calculated according to the following formula:

$$
\varphi_{1}=\frac{1}{1+0.367 \lambda^{0.00725}} \text {. }
$$

In Table 8, the theoretical and experimental values of the eccentric bearing capacity of the hot-rolled H-beam-larch composite columns are compared.
It is seen from Table 8 that the calculated values of eccentric bearing capacity of composite columns were in good agreement with the experimental values, and the maximum error was less than 5\%. The contribution rate of the average bearing capacity of the larch wood board $\left(P_{\mathrm{c}} / P_{\mathrm{u} 2}\right)$ in composite columns was about $32 \%$. Therefore, larch wood board played an important role in the eccentric compressive bearing capacity of composite columns.

\section{Conclusion}

Through experimental research and theoretical comparative analysis, the main conclusions can be drawn:

Hot-rolled H-beam was strengthened by larch wood, and the steel was the main force component. The larch wood provided lateral stiffness for steel and prevented steel from buckling. Therefore, the bearing capacity and stability of the composite column were obviously improved by combining the advantages of the two materials.

In the combination column, hot-rolled H-beam and larch wood work together. The combination effect was outstanding, and the overall performance was excellent. The larch strain and steel plate strain developed synchronously, and the wood strain was always larger than the $\mathrm{H}$-shaped steel strain. When approached the limit load, the larch on the left side with the leg surface reached the compressive strength fracture damage. The hot-rolled H-beam wing edge and web plate reached the yield strength, indicating that the strength of both materials has been fully exerted. The deformation of the steel and wood composite 
column can be divided into the elastic stage and elastic-plastic stage. The failure form of the specimen was ductile damage.

Compared with the composite column that used only structural adhesions, the composite column with bolts was also used on the basis of structural adhesives. The thickness and the size of the cut area of the wood had a great influence on the partial pressure bearing performance of the specimen. The cross-sectional area size of the composite column had the most significant influence.

A simplified calculation formula for the partial pressure bearing capacity of the composite column under the normal operating limit was proposed. From the comparative analysis, it can be seen that the calculated value was in good agreement with the test value, and the error was within $3 \%$, which could meet the actual engineering application needs.

\section{Data Availability}

Data from this manuscript may be made available upon request to the authors.

\section{Conflicts of Interest}

The authors declare that they have no conflicts of interest.

\section{Acknowledgments}

This study was supported by the National Science Foundation of China under Grant no. 5127425. The experiment was supported by the Hunan Engineering Laboratory of Modern Wood Structure Engineering Materials Manufacturing and Application Technology.

\section{References}

[1] X. Qin, C. Liu, and W. Zhang, "Design and research on braced frames steel structure," in Proceedings of the International Conference on Sustainable Development of Critical Infrastructure, vol. 8, pp. 390-403, Shanghai, China, May 2014.

[2] A. D. M. Wahrhaftig and R. F. Carvalho, "Design and construction of wooden structure to replace collapsed steel structure," Practice Periodical on Structural Design and Construction, vol. 21, no. 3, article 05016001, 2016.

[3] Forest Products Laboratory, "Wood handbook-wood as an engineering material," General Tech. Rep. FPL-GTR-190, U. S. Dept. of Agriculture, Forest Service, Forest Products Laboratory, Madison, WI, USA, 2010.

[4] E. F. Hansson, "Analysis of structural failures in timber structures: typical causes for failure and failure modes," Engineering Structures, vol. 33, no. 11, pp. 2978-2982, 2011.

[5] S. De Nardin, "Theoretical-experimental study high strength concrete-filled steel tubes," M. S. thesis, EESC-USP, Sao Carlos, Brazil, 1999, in Portuguese.

[6] L.-H. Han, W. Li, and R. Bjorhovde, "Developments and advanced applications of concrete-filled steel tubular (CFST) structures: members," Journal of Constructional Steel Research, vol. 100, pp. 211-228, 2014.

[7] B. Uy, "Local and postlocal buckling of fabricated steel and composite cross sections," Journal of Structural Engineering, vol. 127, no. 6, pp. 666-677, 2001.
[8] K. K. Choi and Y. Xiao, "Analytical studies of concrete-filled circular steel tubes under axial compression," Journal of Structural Engineering, vol. 136, no. 5, pp. 565-573, 2010.

[9] Z. Ou, B. Chen, K. H. Hsieh, M. W. Halling, and P. J. Barr, "Experimental and analytical investigation of concrete filled steel tubular columns," Journal of Structural Engineering, vol. 137, no. 6, pp. 635-645, 2011.

[10] T. Perea, R. T. Leon, J. F. Hajjar, and M. D. Denavit, "Full-scale tests of slender concrete-filled tubes: axial behavior," Journal of Structural Engineering, vol. 139, no. 7, pp. 1249-1262, 2013.

[11] C. W. Roeder, D. E. Lehman, and E. Bishop, "Strength and stiffness of circular concrete-filled tubes," Journal of Structural Engineering, vol. 136, no. 12, pp. 1545-1553, 2010.

[12] J. Moon, C. W. Roeder, D. E. Lehman, and H.-E. Lee, “Analytical modeling of bending of circular concrete-filled steel tubes," Engineering Structures, vol. 42, pp. 349-361, 2012.

[13] L.-H. Han, G.-H. Yao, and Z. Tao, "Performance of concretefilled thin-walled steel tubes under pure torsion," Thin-Walled Structures, vol. 45, no. 1, pp. 24-36, 2007.

[14] Y. H. Wang, J. G. Nie, and J. S. Fan, “Theoretical model and investigation of concrete filled steel tube columns under axial force-torsion combined action," Thin-Walled Structures, vol. 69, no. 1, pp. 1-9, 2013.

[15] A. Hassanieh, H. R. Valipour, and M. A. Bradford, "Experimental and analytical behaviour of steel-timber composite connections," Construction and Building Materials, vol. 118, pp. 63-75, 2016.

[16] A. Hassanieh, H. R. Valipour, and M. A. Bradford, "Experimental and numerical study of steel-timber composite (STC) beams," Journal of Constructional Steel Research, vol. 122, pp. 367-378, 2016.

[17] A. A. Chiniforush, H. Valipour, A. Akbarnezhad, and M. Bradford, "Steel-timber composite (STC) beams: numerical simulation of long-term behaviour," Ce/papers, vol. 1, no. 2-3, pp. 2051-2059, 2017. 


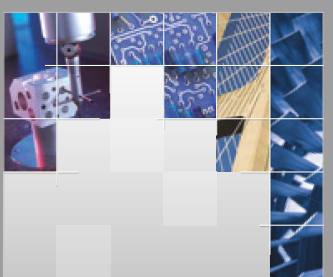

\section{Enfincering}
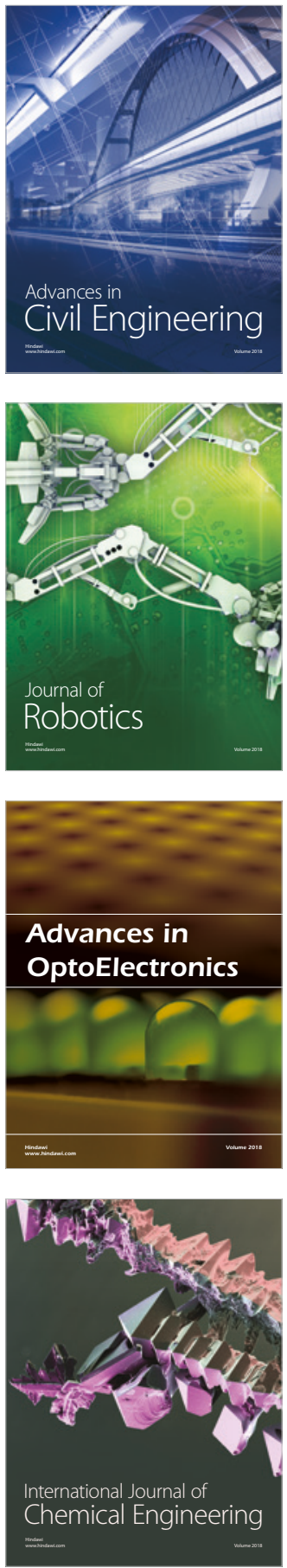

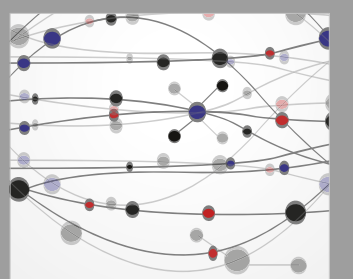

\section{Rotating \\ Machinery}

The Scientific World Journal

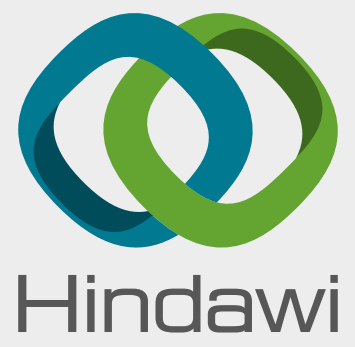

Submit your manuscripts at

www.hindawi.com
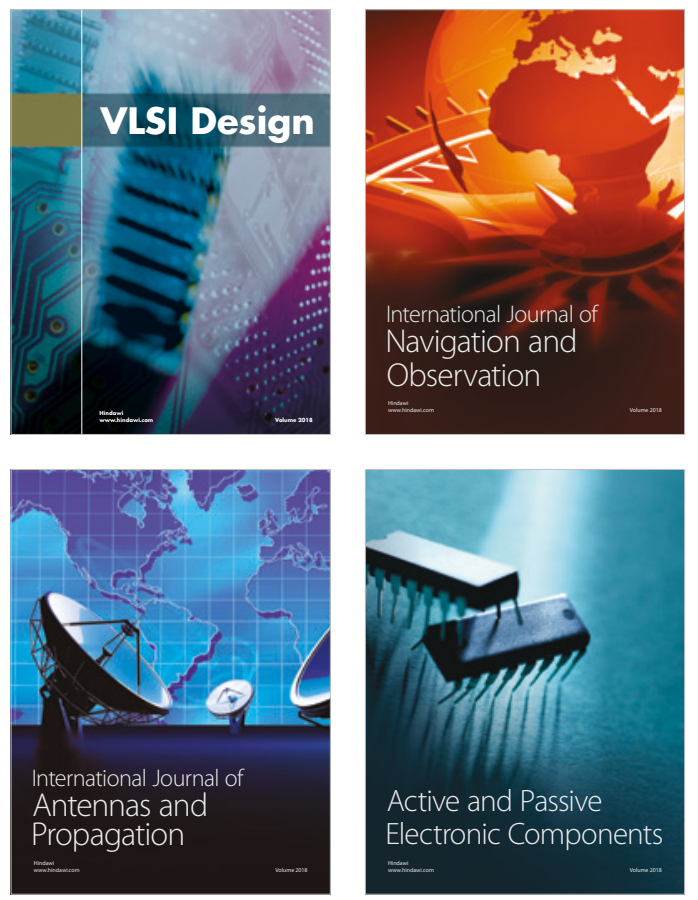
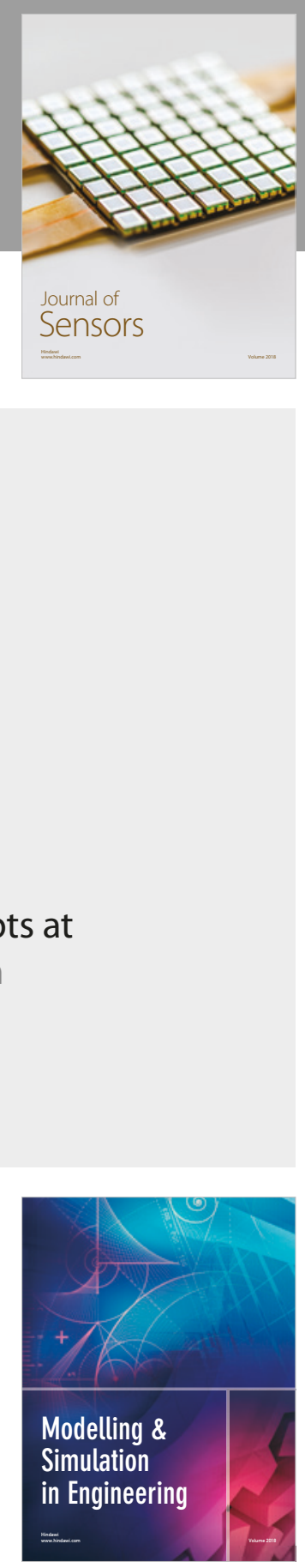

\section{Advances \\ Multimedia}
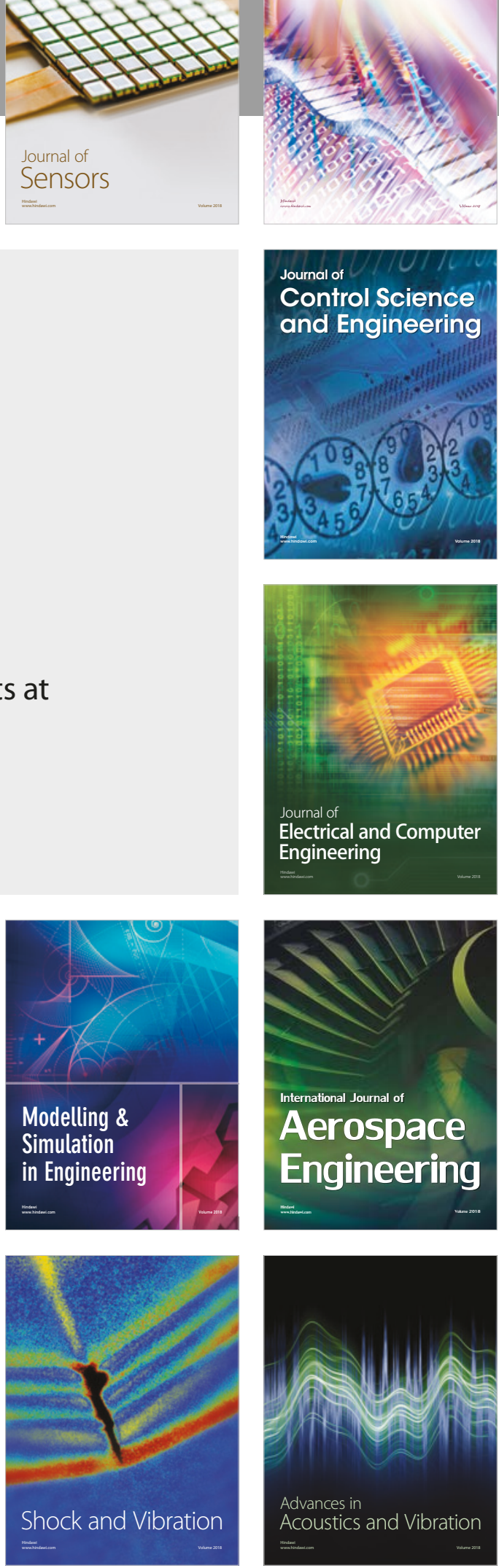